\title{
A GENERIC REVIEW OF THE HYSSURIDAE (CRUSTACEA: ISOPODA) WITH A NEW GENUS AND NEW SPECIES FROM AUSTRALIA
}

\author{
By Gary C. B. Poore and Helen M. Lew Ton \\ Department of Crustacea, Museum of Victoria, Swanston Street, \\ Melbourne, Victoria 3000, Australia
}

\begin{abstract}
Poore, G.C.B. and Lew Ton, H.M. 1988. A generic review of the Hyssuridae (Crustacea: Isopoda) with a new genus and new species from Australia. Memoirs of the Museum of Victoria 49: 169-193.

The isopod family Hyssuridae Wägele is confined to five genera: Belura gen. nov., Hyssura Barnard, Kupellonura Barnard, Neohyssura Amar and Xenanthura Barnard. Ocsanthura Kensley is synonymised with Hyssura, and Kensleyanthura and Belizanthura Kensley are synonymised with Kupellonura. The relationships between the genera are discussed.

Eight new species are described: $B$. pillara, $K$. biriwa, $K$. currawan, $K$. gidgee, $K$. marrongie, $K$. werawera, $N$. bilara and $X$. ulawa; and a key to separate the five genera and the Australian species is presented.
\end{abstract}

\section{Introduction}

The Hyssuridae is a family of primitive anthuridean Isopoda first separated from the Anthuridae and Paranthuridae, the other two families of the infraorder, by Wägele (1981a). Members of the family are distinguished from other anthurideans by the absence of a telsonic statocyst, free pleonites, non-operculiform first pleopods (all pleopods are similar) and small size. In this contribution Wägele's (1981a, b) original concept of the Hyssuridae is confined (only four of the original ten genera are recognised as being valid) and a new genus is added. The systematics of the Hyssuridae and the relationships of the genera are discussed. A key to the five genera and to the Australian species is presented. Each genus is diagnosed and eight new species in four genera from Australia are described.

Abbreviations used in figures are: A1, A2, antennae 1 and 2; E, pleonal epimera; $\mathrm{MD}$, mandible; MP, maxilliped; MX1, maxilla 1; P1-P7, pereopods 1 to 7; PL1-PL5, pleopods 1 to 5; T, telson; UN, uropodal endopod (or endopod fused to peduncle); UX, uropodal exopod (flattened); l, left; $r$, right. On pleopods and male antennae 1 only representative setae or aesthetascs are drawn. Unless noted otherwise figures are of left limbs. The letters a, b, c, refer to separate figured individuals.

The Greek prefixes hyssos and belos mean javelin or spear and allude to the shape of the tail of species of the type genus. The specific epithets chosen for new species are Australian aboriginal words meaning spear and are nouns in apposition.
Material is lodged in the Museum of Victoria, Melbourne (NMV), Australian Museum, Sydney (AM), Queensland Museum, Brisbane (QM), and National Museum of Natural History, Washington (USNM). The station number prefixes for samples from Western Port, Bass Strait, and others from tropical Australia are taken from the Museum of Victoria's "station" data-base.

\section{Systematics of the Hyssuridae}

Wägele (1981a: fig. 30; 1981b) listed ten genera belonging to the Hyssuridae. The family was defined on the basis of two apomorphies: the body being very slender and the mouthparts of adult males being partly reduced. Our dissections of males show little evidence of mouthpart reduction. The genera were separated from the remaining two families of the Anthuridea (Anthuridae and Paranthuridae) whose synapomorphies were said to be the presence of telsonic statocysts and operculiform first pleopods.

Wägele's (1981a) cladistic analysis divided the genera into two groups, $\mathrm{A}$ and $\mathrm{E}$. The four genera of genus-group E (Rhiganthura Kensley, Stellanthura Wägele, Heptanthura Kensley and Eisothistos Haswell) were defined on the basis of several synapomorphies. At least three of these characters clearly separate the genera from group A and align them with the non-hyssurid Anthuridea: long uropodal peduncle; sexually dimorphic pleon; and enlarged first pleopod. More importantly, these genera share shortened pleonites and the absence of a 


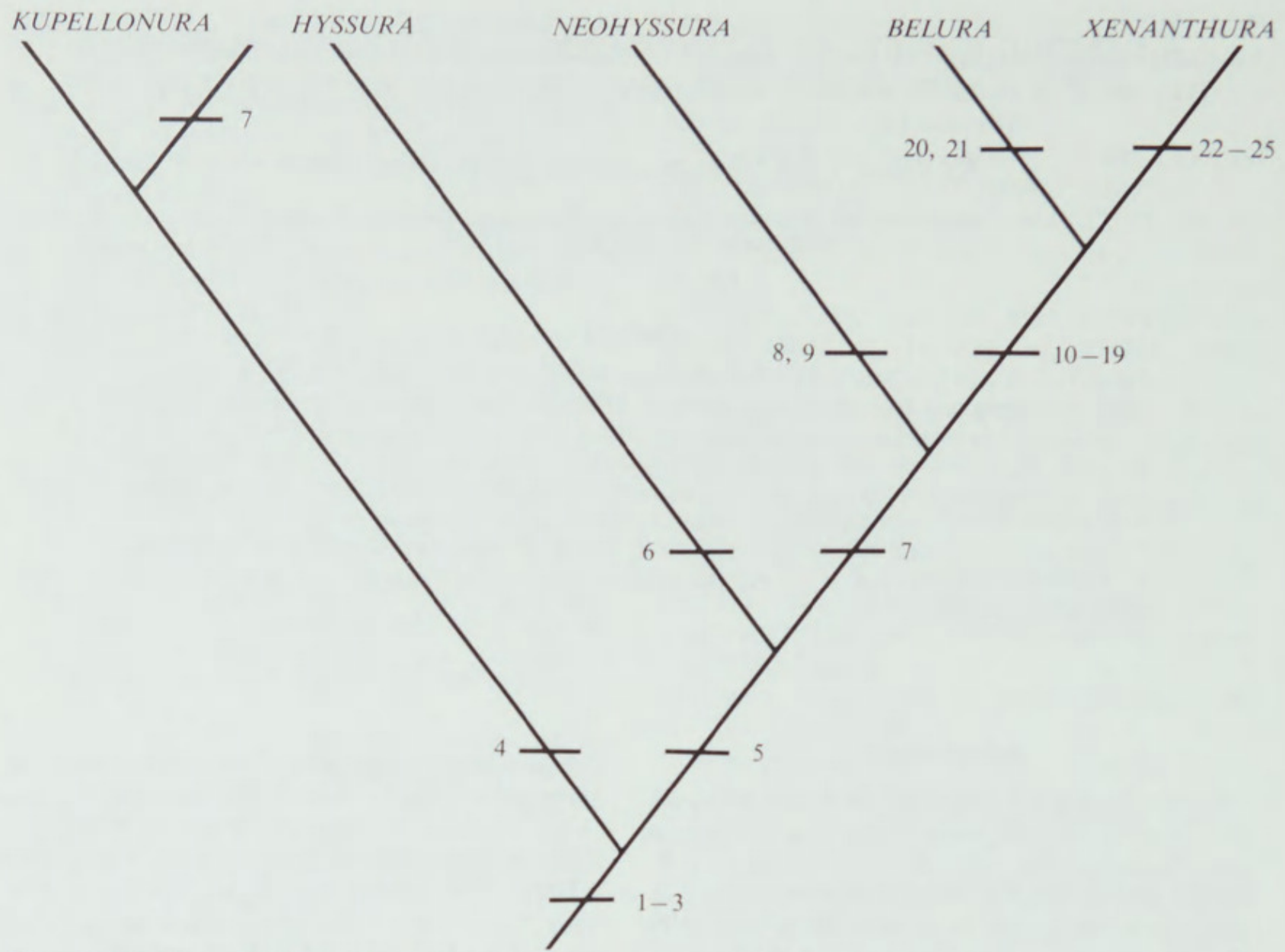

Figure 1. Cladogram depicting relationships between the five genera of the Hyssuridae. Apomorphies of the family and of each clade and genus are numbered and explained below. The character state in brackets is the plesiomorphic state.

1. Body small and slender (larger and wider).

2. Pereopods 2 and 3 subchelate and with carpus produced posterodistally (similar to pereopods 4-7).

3. Antenna 1 flagellum of 4 articles with aesthetascs on second and last articles (several articles with at least 1 aesthetasc on all articles except the first and last).

4. Uropodal exopod with a lateral lobe (no lobe).

5. Mandibular molar process acute (blunt).

6. Pereopods 4-7 with carpus rectangular (triangular).

7. Antenna 1 with 1 aesthetasc on last article only ( 1 aesthetasc on second and last articles).

8. Telson evenly tapering (more or less parallel-sided).

9. Telson and uropodal exopod with lateral spines (no spines).

10. Antenna 1 flagellum of 3 articles, first elongate, (4 articles of similar lengths).

11. Antenna 2 flagellum of 6 or fewer articles ( 8 or more articles).

12. Antenna 2 peduncle with a specialised plumose seta with a swollen base (no such seta).

13. Mandibular molar process an articulating toothed spine (simple non-articulating process).

14. Mandibular palp a single article ( 3 articles).

15. Maxillipedal palp articles fused (free).

16. Pleopodal endopods with 1 plumose seta ( 4 or more setae).

17. Uropodal endopod fused to peduncle (free).

18. Uropodal exopod medially expanded (not expanded).

19. Telson shortened (about as long as uropodal endopod).

20. Telson with an apical spine (no spine).

21. Pereopod 3 carpus with an acute posterodistal projection (carpus more rounded).

22. Pereopod 3 merus and carpus with a posterior brush of long setae (few setae).

23. Male with tri-partite eye (simple enlarged eye).

24. Male appendix masculina with apical spines (no spines).

25. Pleopods 2-5 of male of 1 article ( 2 articles). 
produced carpus on pereopods 2 and 3 with the Anthuridae and Paranthuridae. The only synapomorphies of group E which are unique are a broadened tail fan and a strong projection on the uropodal exopod. For these reasons we exclude these genera from the Hyssuridae believing them to be more closely allied to the Anthuridae s.s.

The Hyssuridae, therefore, in the sense used in this contribution comprises only those genera included in Wägele's genus-group A.

The family is diagnosed largely on the basis of numerous plesiomorphies but there are undisputed apomorphies of which small size and slender form are two. Wägele defined genus-group A on characters M.1 and M.2 (1981a, fig. 30) as follows:

Pereopods 2 and 3 are subchelate. This is a probable apomorphy if a similar condition in the Paranthuridae is independantly derived.

The carpus of pereopods 2 and 3 is posterodistally produced. Similar structures are not seen elsewhere in other anthuridean families.
The flagellum of antenna 1 has at most four articles with one aesthetasc on the terminal article and primitively one on the second. This condition is not seen elsewhere and is a unique apomorphic state derived from a longer flagellum with at least one aesthetasc on every article except the first and the last (Wägele, 1981, 1983). In other Anthuridea the terminal aesthetasc-free article may also be lost and the last of the remaining articles may carry more than one aesthetasc.

The apomorphies of the family are summarised in Fig. 1.

Two of the six genera of genus-group A listed by Wägele, Ocsanthura Kensley and Kensleyanthura Wägele, are reduced to junior synonyms. The family now includes Hyssura Barnard, Kupellonura Barnard, Neohyssura Amar, Xenanthura Barnard and the new genus Belura.

Our intuitive interpretation of the phylogeny of the five genera differs from that hypothesised by Wägele (1981a: 69-72, fig. 30). The relationships be-

\section{Key to World genera and Australian species of Hyssuridae}

1. Uropodal exopod as broad or broader than long, endopod fused to peduncle; pleopodal endopods with single apical seta; mandibular palp of 1 article with seta $\ldots \ldots \ldots \ldots 2$

- Uropodal exopod longer than wide, endopod free; pleopodal endopods with several margi-

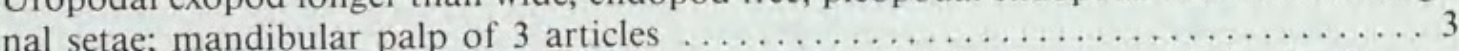

2. Pereopod 3 merus and carpus with tufts of long setae; telson short, excavate apically; eyes

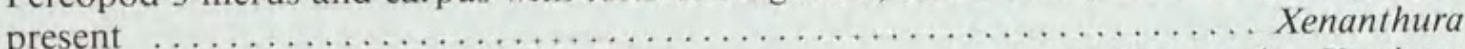
one Australian species X. ulawa

- Pereopod 3 merus and carpus acutely produced posterodistally; telson with apical projection; eyes absent $\ldots \ldots \ldots \ldots \ldots \ldots \ldots$ Belura one Australian species $B$. pillara

3. Uropodal exopod linear, its medial margin and lateral margins of telson with cuticular spines Neohyssura one Australian species $N$. bilara

- Uropodal exopod linear or with lateral lobe, unarmed; telson unarmed $\ldots . . . . .44$

4. Pereopod 2 propodus palm oblique; pereopods $4-7$ with carpus quadrangular, with 2 marginal spines; molar acute $\ldots \ldots \ldots \ldots \ldots$ Hyssura (not known from Australia)

- Pereopod 2 propodus palm axial; pereopods $4-7$ with carpus triangular, with 1 marginal spine; molar blunt .............................. Kupellonura . . 5

5. Uropodal exopod linear (about 3 times as long as wide) $\ldots \ldots \ldots \ldots \ldots . .$. marrongie

- Uropodal exopod laterally lobed (little more than twice as long as wide) .........6 6

6. Lateral margins near base of telson and uropodal endopod, and mesial margin of base of uropodal exopod each with 2 recurved hooks .................... currawan

- Margins not so armed, dentate at most . ......................... 7

7. Uropodal exopod with lateral lobe proximal; apex of telson evenly tapering over distal third

- Uropodal exopod with lateral lobe widest at midpoint; apex of telson broadly rounded 8

8. Telson apex rounded, apex weakly produced (temperate) $\ldots \ldots \ldots \ldots \ldots \ldots$. birawa

- Telson apex rounded-truncate with definite apical setiferous protuberance (tropical) 
tween them and the apomorphies defining each monophyletic group and genus are given in fig. 1 . With the exception of the synapomorphies of $\mathrm{Be}$ lura and Xenanthura (characters 10-19) those characterising the other genus-groups are not strong. But only one homeoplasy is seen: some species of Kupellonura share with Xenanthura, Belura and Neohyssura the loss of one aesthetasc (character 7).

\section{Hyssuridae Wägele} 48.

Hyssuridae (genus-group A) Wägele, 1981a: 68,-1981b:

Diagnosis. Pleon elongate (about as long as pereonites 6 and 7); pleonites free, little wider than long.

Antenna 1 flagellum of 3-4 articles, with 1 aesthetasc on last article and sometimes on article 2. Antenna 2 flagellum of 5-9 articles. Mouthparts compact, not piercing. Mandibular molar process an acute spine, blunt or reduced; palp of 1 or 3 articles. Maxilliped narrow; endite short or reaching to second palp article; palp of 5 free articles or single article.

Pereopods 1-3 subchelate, pereopod 2 as large as 1 or larger; basis linear, carpus posterodistally produced. Pereopods 4-7 carpus triangular (rectangular in Hyssura); with 0-2 posterior carpal spines and $0-2$ posterior propodal spines. Pleopods $1-5$ of equal length; pleopod 1 not operculiform. Uropodal peduncle short (about one-third of total length); exopod attached basally.

Telsonic statocysts absent.

Male antenna 1 flagellum of 4-12 isometric aesthetasc-bearing articles.

\section{Belura gen. nov.}

Diagnosis. Antenna 1 of 3 articles, with 1 aesthetasc on terminal article. Antenna 2 peduncle with plumose setae distally (in addition to typical brush setae) of which most ventral has swollen base. Mandibular molar process an articulating toothed spine; palp a single article with terminal seta. Maxillipedal endite short; palp of fused articles.

Pereopod 2 palm almost transverse, carpus barely produced. Pereopod 3 dactylus, carpus and merus all acute distally. Pereopods 4-7 carpus triangular, very short or without anterior margin, without posterior carpal and propodal spines. Pleopodal endopods triangular, with terminal seta; exopods ovoid, setose. Uropodal endopod fused to peduncle; exopod ovoid. Telson shorter than uropods, with strong apical projection.

\section{Type species. Belura pillara sp. nov.}

Etymology. From the Greek belos (dart) and ura (tail) alluding to the shape of the apex of the telson (feminine).

Remarks. The new genus Belura is very similar to Xenanthura Barnard with which it shares similarities in the structure of antennae 1 and 2, pereopods 4-7, pleopods and uropods. The most obvious differences are in the presence of eyes, structure of pereopod 3 and the telson. The lamina dentata and male appendix masculina also differ. The male antenna 1 of Belura is shorter than that of Xenanthura but males of few species are known.

The south-western Atlantic species, B. acuticauda (George and Negoescu) comb. nov. should be removed from Xenanthura to the new genus. In doing so, Belura is then confined to two species from cool temperate waters while the remaining six species of Xenanthura are more tropical (George and Negoescu, 1985).

\section{Belura pillara sp. nov.}

Figures 2-4

Material examined. 48 juveniles, 6 mancas, 1 male; to 3.5 $\mathrm{mm}$.

Holotype: Bass Strait, $75 \mathrm{~km} \mathrm{~S}$ of Wilsons Promontory, $\left(39^{\circ} 49.5^{\prime} \mathrm{S}, 146^{\circ} 18.5^{\prime} \mathrm{E}\right), 82 \mathrm{~m}$, shell-bryozoan mud, Smith-McIntyre grab, G.C.B. Poore et al. on RV "Tangaroa", 13 Nov 1981 (stn BSS-158), NMV J15001, juvenile, $3.5 \mathrm{~mm}$ (with 2 slides).

Paratypes: Type locality. NMV J15002 (male, with 2 slides), NMV J15003 (10 juveniles, with 1 slide) J15004 (3 mancas), AM P37926 (5 juveniles), USNM 211448 (5 juveniles).

Other material: Bass Strait. Type locality (epibenthic sled sample), NMV J15005 (2); Eastern slope ( $39^{\circ} 28.2^{\prime}$ S, $\left.148^{\circ} 52.4^{\prime}\right), 841 \mathrm{~m}$, muddy sand, naturalist's, dredge, G.C.B. Poore on HMAS "Kimbla", 29 Mar 1979 (stn BSS-37), NMV J15006 (1 post-manca). S of Point Hicks (38 $17.7^{\prime}$ S, $\left.149^{\circ} 11.3 \mathrm{E}\right), 400 \mathrm{~m}$, coarse sand and gravel, epibenthic sled, M. Gomon et al. on RV "Franklin", 24 Jul 1986 (stn SLOPE-40), NMV J14466 (2). Eastern Gippsland (37 59 S, $\left.148^{\circ} 27^{\prime} \mathrm{E}\right), 51 \mathrm{~m}$, muddy sand (stn BSS-207), NMV J15007(9); (37 $\left.50^{\circ} \mathrm{S}, 148^{\circ} 40 \mathrm{E}\right), 26 \mathrm{~m}$, medium sand (stn BSS-208), NMV J15008(2)-both epibenthic sled, M. Gomon and R. Wilson on FV "Silver Gull", 30 Jul 1983.

Vic. Western Port, off Crib Point ( $\left.38^{\circ} 21^{\prime} \mathrm{S}, 145^{\circ} 14^{\prime} \mathrm{E}\right)$, 10-19 m, sandy sediments, 1964-1972 (CPBS stations), NMV J15009-J15016 (10 specimens). Western Port, Western Entrance, 10-23 m, sandy sediments, 1974: stn WBES1742, NMV J15017 (3); stn WBES-1748, J15018 (1)

Description. Body 18 times as long as wide, colourless. Head about as wide as long, without eyes. Antenna 1 articles 1, 2 and 3 with 1, 2, 0 brush-setae respectively; flagellum of 3 articles, first with brushseta, last with 1 aesthetasc, 1 plumose seta, 1 sim- 


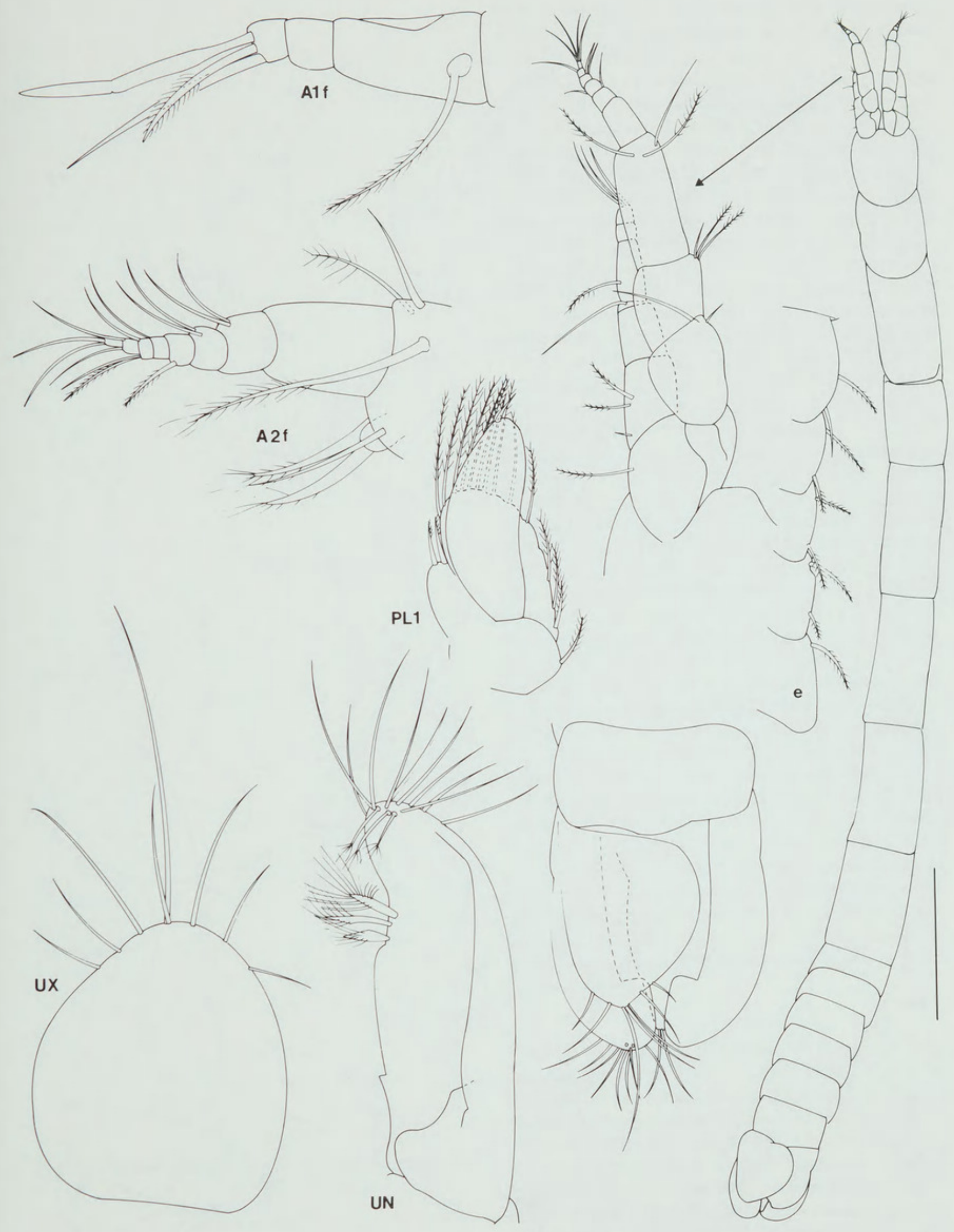

Figure 2. Belura pillara, holotype (f, flagellum in lateral view; scale $=0.5 \mathrm{~mm}$ ). 


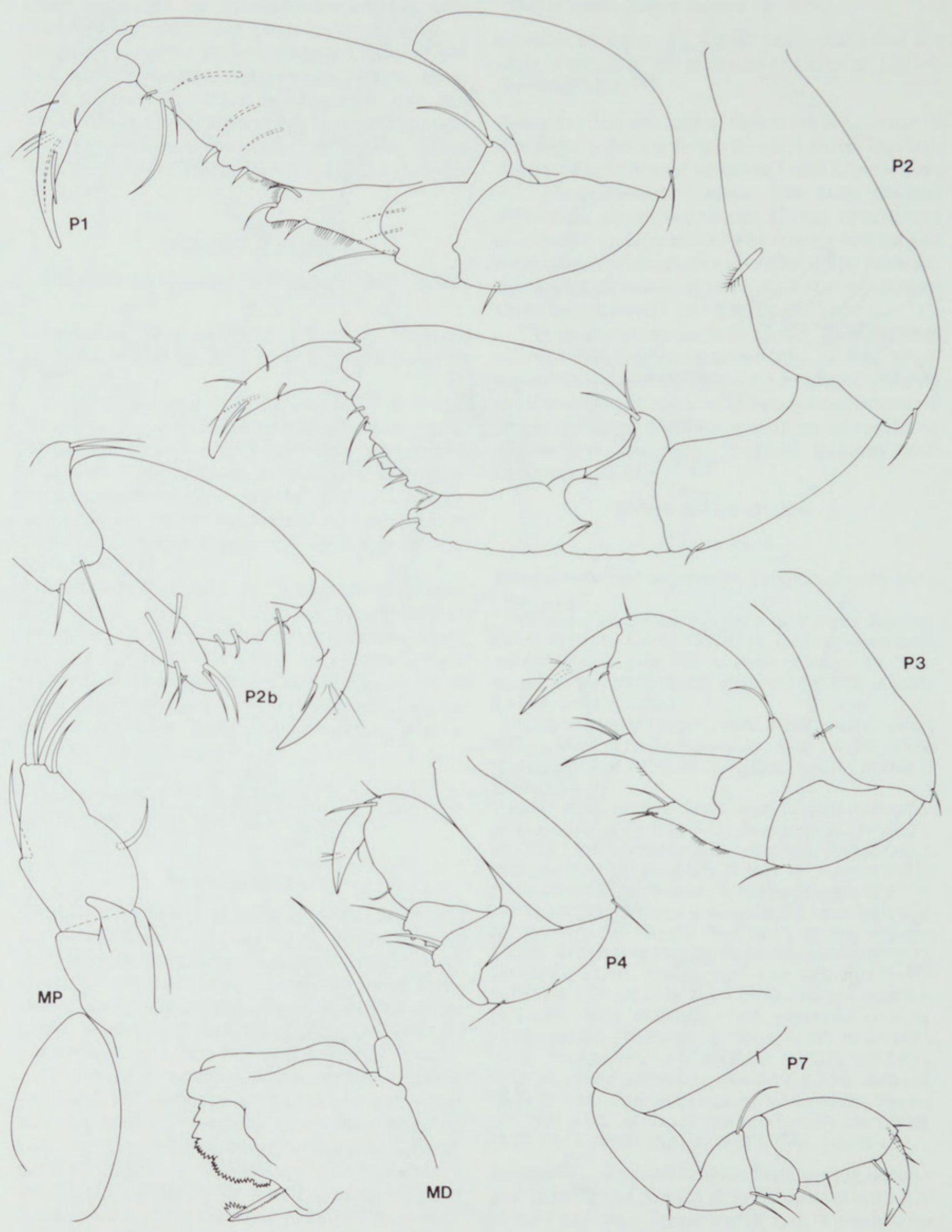

Figure 3. Belura pillara, holotype; b, paratype male, NMV J15002. 


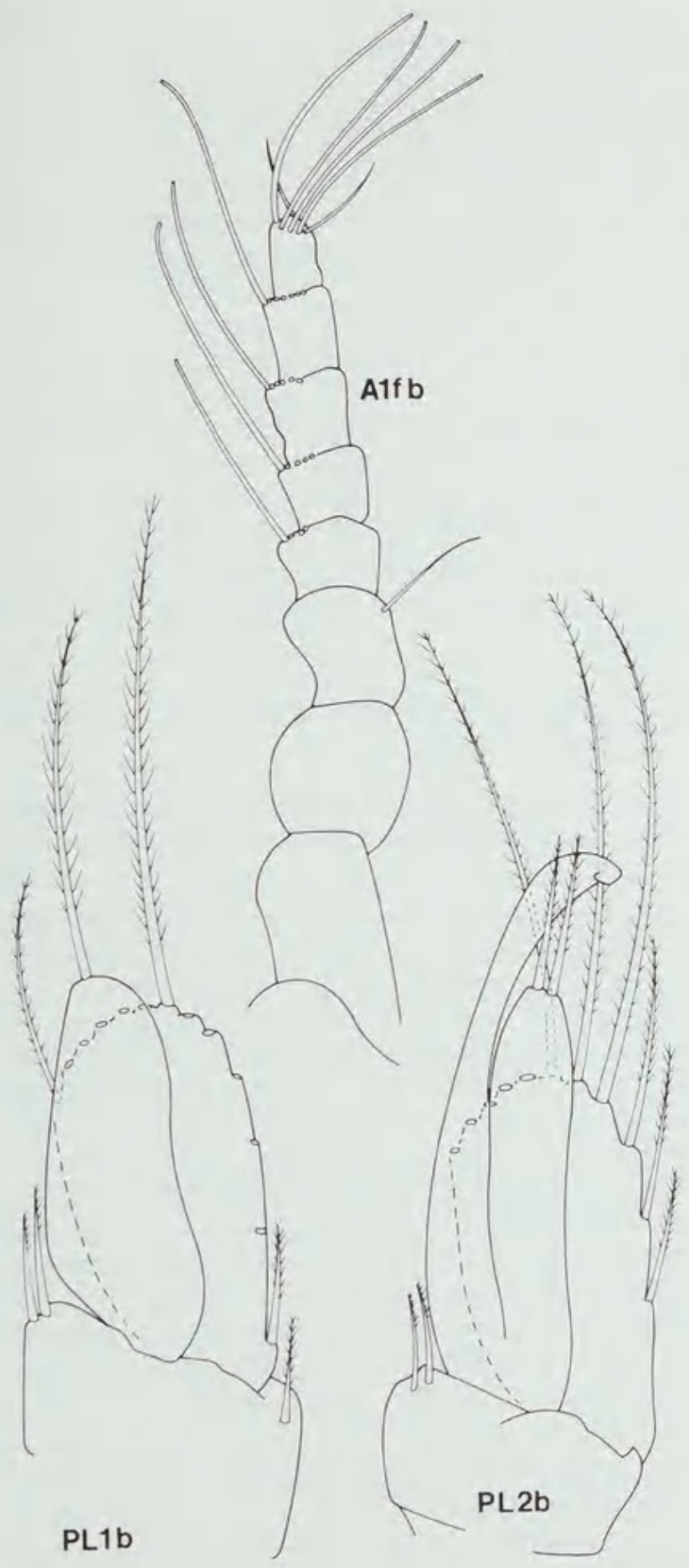

Figure 4. Belura pillara, holotype; b, paratype male, NMV J15002. ple seta. Antenna 2 articles 4 and 5 with brush-setae, article 5 with ventral plumose setae of which base is swollen; flagellum of 8 articles.

Mandible with bluntly toothed incisor; lamina dentata of 3 finely denticulate plates, most distal with additional coarser teeth; molar process an articulating spine with row of fine denticles along its length and longer teeth at apex; palp a narrow article with long apical seta. Maxilla 1 with 7 apical setae. Maxilliped with short endite; palp a single plate with 1 mesial, 1 lateral and 4 distal setae.

Pereopod 1 carpus slightly produced posterodistally; propodus elongate, about 2.5 times as long as wide; palm axial with 2 proximal pectinate setae, 2 short simple setae, and 2 long and 1 short setae distally; 3 mesial setae. Pereopod 2 carpus slightly produced posterodistally; propodus almost twice as long as wide; palm oblique with pectinate setae, 2 short setae proximally, 1 short and 1 longer setae distally. Pereopod 3 merus and carpus acutely produced posterodistally; propodus almost twice as long as wide; palm oblique with pectinate setae, 2 short setae proximally, 1 short and 1 longer setae distally. Pereopod 3 merus and carpus acutely produced posterodistally; propodus 1.4 times as long as wide, palm straight. Pereopods 4-7 with few posterior setae; merus with digitiform denticles posteriorly; palm sinuous, unarmed; propodus of pereopods 5-7 with 2 distomesial spines.

Pleopod 1 peduncle with 2 setae on mesial lobe; endopod with 1 distal seta; exopod half length of endopod, with 13 marginal plumose setae. Pleopods 2-5 similar to first. Pleonal epimera 1-4 with 2 and epimeron 5 with 1 marginal plumose setae.

Uropodal peduncle and endopod fused, with broad ventromesial shelf bearing 3 large brush-setae in distal concavity; apex rounded, with 3 finer brush-setae and 10 simple setae; exopods overlapping, roughly semicircular, little longer than wide, with 8 setae distally. Telson not reaching to uropodal apices, widest proximally, narrowing gradually to 0.8 length, then abruptly narrower to apical spike, 2 apical setae.

Male. Antenna 1 flagellum of 5 articles each bearing about 6 aesthetascs. Pereopod 1 similar to juvenile except mesial propodal setae. Pereopod 2 carpus strongly produced posterodistally, with apical setae; palm more transverse. Pleopod 1 peduncle more rectangular; exopod almost as long as endopod. Pleopod 2 with narrow endopod with 2 apical spines; appendix masculina exceeding endopod, broad, apically curved. Pleopods $2-5$ exopods of a single article. 
Distribution. Victoria (Western Port only) and Bass Strait, coarse shelly sediments, $10-841 \mathrm{~m}$.

Remarks. Belura pillara differs from B. acuticauda (George and Negoescu) from the South Atlantic, the only other species in the genus, in small ways. Pereopods 1 and 2, the pleopods and the telson are more elongate. The maxilliped bears a lateral seta not shown in B. acuticuda but this seta is usual in many anthurideans.

\section{Hyssura Norman and Stebbing}

Hyssura Norman and Stebbing, 1886: 128.-Barnard, 1925: 137.-Wagele, 1981a: 70-75, 103.-1981b: 49.

Ocsanthura Kensley, 1978: 558 (type species Ocsanthura vimsae Kensley, 1978) new synonym.

Oscanthura Kensley.-Wägele, 1981a: 70, 72, 74, 103.1981b: 49 (lapsus calami).

Diagnosis. Antenna 1 flagellum of 4 articles with 1 aesthetasc on each of second and terminal articles. Antenna 2 peduncle without stout plumose setae. Mandibular molar process acute; palp of 3 articles. Maxillipedal endite reaching to second palp article, apex acute; palp of 5 free articles.

Pereopod 2 palm oblique, with marginal spines. Pereopods 4-7 carpus rectangular; with 1-2 posterior carpal spines and 1 posterior propodal spine. Pleopodal rami ovoid, setose. Uropodal exopod longer than wide. Telson evenly tapering.

Type species. Hyssura producta Norman and Stebbing, 1886 (monotypy).

Remarks. Five species are known, all from the Atlantic or Mediterranean; no species are recorded from Australia. Wägele (1981b) redescribed the type species from the only specimen known. He implied that this specimen is a manca and that the absence of a seventh pair of legs does not characterise the genus. Wägele's second species, $H$. ligurica, has seven pairs of pereopods. All three species of $O \mathrm{C}$ santhura must be removed to Hyssura since the only features supposed to distinguish the genus, presence of pereopod 7 and a statocyst, are not real. Our examination of type material of $H$. vimsae (Kensley) comb. nov., type species of Ocsanthura, has shown that contrary to the original diagnosis no statocysts are present. In this the species agrees with $H$. bacescui (George and Negoescu) comb. nov. and probably $H$. gracilis (Kensley) comb. nov.

The genus Hyssura retains the most plesiomorphies of any anthuridean. Its apomorphy is the enlargement of the carpus of pereopods 4-7. Its species are most similar to those of Kupellonura which differ in the presence of a laterally-lobed uropodal exopod.

\section{Kupellonura Barnard}

Kupellonura Barnard, 1925: 146.-Wägele, 1981a: 7175. -1981b: 55.-Kensley, 1982a: 126.

Horoloanthura.-Kensley, 1975: 75 (partim) (not Horolanthura Menzies and Frankenberg, 1966).

Kensleyanthura Wägele, 1981a: 106.-198lb: 82 (type species Kupellonura capensis Kensley, 1975) new synonym.

Belizanthura Kensley, 1982b: 338 (type species Belizanthura imswae Kensley, 1982).

Diagnosis. Antenna 1 flagellum of 4 articles, with 1 aesthetasc on terminal article and sometimes 1 on second article. Antenna 2 peduncle without stout plumose setae. Mandibular molar process a simple blunt tooth; palp 3-articled. Maxilliped with endite reaching third palp article; palp of 5 articles.

Pereopods 2 and 3 palm axial, with marginal spines. Pereopods 4-7 carpus triangular, carpus and propodus each with 1 posterodistal spine. Pleopodal rami both with several marginal setae. Uropodal endopod free, longer than peduncle; exopod foliar or narrow. Telson spatulate, about as long as uropods.

Type species. Kupellonura mediterranea Barnard, 1925 (monotypy).

Remarks. The complex synonymy of Kupellonura has been discussed by Kensley (1982a) and Negoescu and Wägele (1984). Eight species are known from the Atlantic, Mediterranean, New Zealand and Caribbean (Negoescu and Wägele, 1984; Wägele, 1985; George and Negoescu, 1985).

The genus is most easily recognised by the uropodal exopods, held obliquely erect in preserved material and usually with a lateral lobe. The first species, $K$. birawa, is figured and described in detail. The general form, number of articles and setation of the antennae, shape and setation of the pereopods and pleopods, and mouthparts of all other species were examined in detail but only the telson and uropods which are diagnostic are consistently figured. Differences in setation or proportions are noted and figured only where they are significantly different from $K$. biriwa.

In all Australian species the flagellum of antenna 1 has only one aesthetasc (on the terminal article). This condition is shared with $K$. formosa (Menzies and Frankenberg) and $K$. racovitzai George and Negoescu. All other species have two aesthetascs (George and Negoescu, 1985, and literature cited therein).

The male of $K$. gidgee is figured. The aesthetascbearing flagellum of antenna 1 is of 5 articles in this and other species. The male has larger eyes and lacks the pleonal epimeral setae found on juveniles. 
Uropodal rami and the telson are narrower than in juveniles.

Species of Kupellonura are unusual in the possession of a tessellated cuticle on the dorsal surface of the antennal peduncles, head and pereonite 1 . A mosaic of small tessae is visible under Nomarski illumunation at 400 times (Fig. 10). The fact that it has not been reported elsewhere in the Anthuridea may reflect the techniques used for examination more than reality.

\section{Kupellonura biriwa sp. nov.}

Figures 5-8

Material examined. 9 juveniles, 1 manca, 2 males; to 4.5 $\mathrm{mm}$.

Holotype: Victoria, Western Port, exact locality not recorded $\left(38^{\circ} \mathrm{S}, 145^{\circ} \mathrm{E}\right)$, Marine Studies Group, early 1970s, NMV J15019, juvenile, $4.5 \mathrm{~mm}$ (with 2 slides).

Paratypes: Vic., type locality, NMV J15020 (3 juveniles). Western Port, $\left.38^{\circ} 29.78^{\prime} \mathrm{S}, 145^{\circ} 06.28^{\prime} \mathrm{E}\right)$ sand, $24 \mathrm{~m}, 25$ Nov 1974 (stn WBES-1746), NMV J15021 (male, $3.1 \mathrm{~mm}$, with 2 slides); J15022 (1 juvenile); off Sandy Point, French Is. $\left(38^{\circ} 21.6^{\prime} \mathrm{S}, 145^{\circ} 30.6^{\prime} \mathrm{E}\right.$ ), sand, $9 \mathrm{~m}, 26$ Nov 1973 (stn WBES-1735), J15023 (manca, $2.3 \mathrm{~mm}$ ); Crib Point $\left(38^{\circ} 21^{\prime} \mathrm{S}, 145 \mathrm{~S}^{\circ} 14^{\prime} \mathrm{E}\right)$, sand, $9-13 \mathrm{~m}, 1964-1965$ - stn CPBSA4, J15024 (1 juvenile); stn CPBS-23S, J15025 (1 juvenile); stn CPBS-33S, J15026 (1 male).

Other material examined. NSW, Hawkesbury River, A. Jones, 1978, AM P29754 (with 2 slides), P29756, P29757 (3 specimens).

Description. Body 20 times as long as wide, colourless. Head longer than wide, acute rostrum, lateral eyes. Antenna 1 peduncle with few fine brush-setae; flagellum with short first article, second longer, plus 2 shorter, with terminal aesthetasc. Antenna 2 flagellum of 9 articles.

Mandible incisor bluntly toothed; lamina dentata finely denticulate proximally, with coarser teeth distally; molar process rounded; palp articles 1 and 2 each with 1 seta, last article recurved, with 3 setae. Maxilla 1 inner lobe with 1 terminal seta, outer lobe strongly curved, with 1 strong plus 3 finer apical teeth. Maxillipedal endite narrow, with 1-2 terminal setae; palps asymmetrical, articles 1-5 with 0 , 1,1 or 2,1 or 2 , and 4 setae respectively.

Pereopod 1 carpus slightly produced posterodistally, with marginal and subterminal spines; propodus 1.8 times as long as wide, palm with 2 marginal spines and blade-like setae on cutting edge, 3 mesial setae. Pereopod 2 carpus strongly produced posterodistally, with marginal and subterminal spines; propodus with 2 spines with accessory flagella and blade-like seta on cutting edge, 1 submarginal seta distally. Pereopod 3 similar to pereopod 2 but propodus smaller. Pereopods 4-7 carpus triangular, with short anterior margin, carpus and propodus each with posterodistal spine. Pleopod 1 peduncle short, rectangular; endopod longer than exopod, with 5 plumose setae; exopod with 11 plumose setae. Pleopods $2-5$ similar to first. Pleonal epimera 1-4 with 5 submarginal plumose setae and 1 smaller simple seta; epimeron 5 with 1 plumose plus 2 simple setae.

Uropodal endopod about twice as long as peduncle, 1.8 times as long as wide, apex broadly rounded, with about 16 long setae. Exopods overlapping, as long as endopod and telson, 1.8 times as long as wide, widest at midpoint; mesial margin gently convex, dentate; lateral margin strongly convex; apex acute, with 10 setae. Telson basally narrow, 2.1 times as long as wide, concave dorsally and with broad ventral longitudinal ridge; lateral margins straight, denticulate distally; apex rounded over last third, with 12 apical setae.

Male. Head narrower than in juvenile, eyes large. Antenna 1 flagellum with 5 aesthetasc-bearing articles plus basal and terminal articles. Maxilliped similar but endite absent. Pereopod 1 propodus narrower, palm with 4 mesial and 5 marginal setae. Pleopods more elongate; pleopods 2-5 with 2 articulate exopods. Pleopod 2 with hooked appendix masculina.

Distribution. Victoria (Western Port) and New South Wales (Hawkesbury River), 9-24 m.

Remarks. Three specimens from the Hawkesbury River, NSW, differ slightly from the type material (fig. 8). The pereopods and uropods are narrower than in the Victorian material but the details of setation are identical. In view of the small number of specimens available these are not recognised as a separate species.

The species is confined to marine bays of southeastern Australia. A single specimen of Kupellonura from nearby Bass Strait (Kupellonura sp. herein) is considered a separate species.

The dentate margins of the telson and uropodal exopod are similar to those seen in $K$. serritelson Wägele.

\section{Kupellonura currawan sp. nov.}

Figure 9

\section{Material examined. Unique.}

Holotype: NSW, off Nowra ( $\left.34^{\circ} 51.9^{\prime} \mathrm{S}, 151^{\circ} 12.6^{\prime} \mathrm{E}\right)$, crinoid dominated community, $777 \mathrm{~m}$, G.C.B. Poore and C.C. Lu on RV "Franklin", 15 Jul 1986, epibenthic sled (stn SLOPE-6), NMV J14477, juvenile, $6.5 \mathrm{~mm}$ (with 2 slides).

Diagnosis. Antenna 1 with 1 aesthetasc. Uropodal endopod 2.5 times as long as wide, dorsolateral 


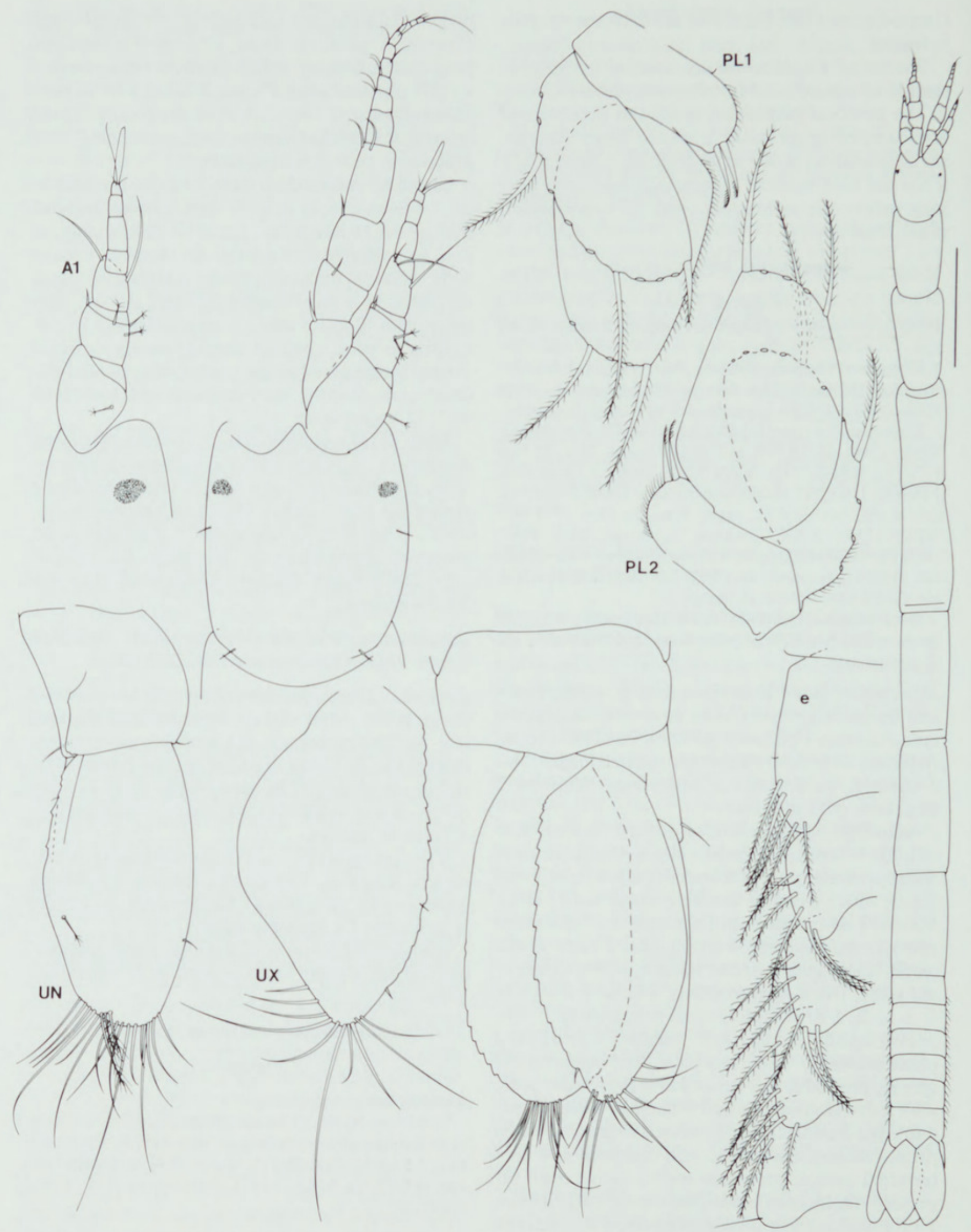

Figure 5. Kupellonura biriwa, holotype (scale $=0.5 \mathrm{~mm})$. 


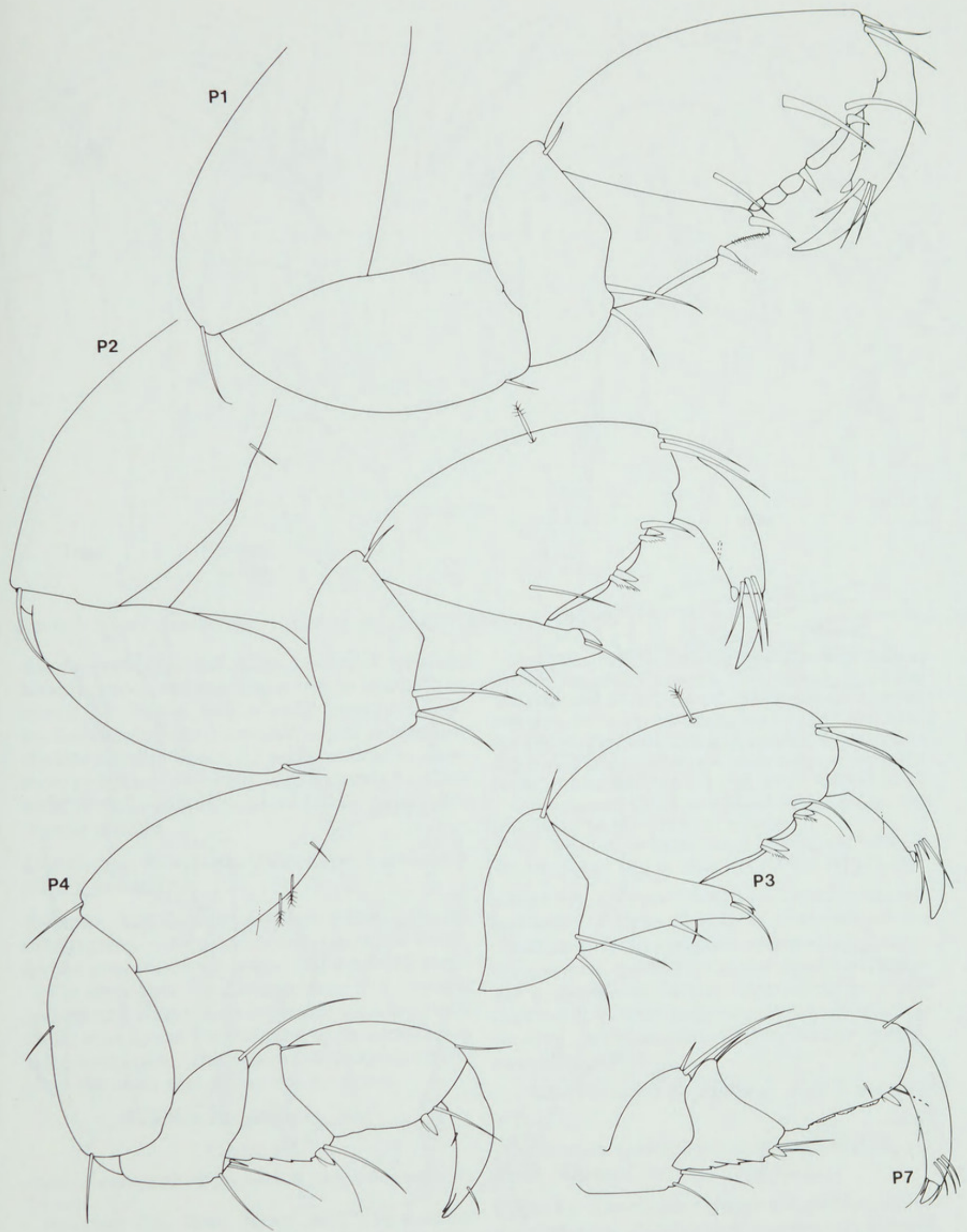

Figure 6. Kupellonura biriwa, holotype. 


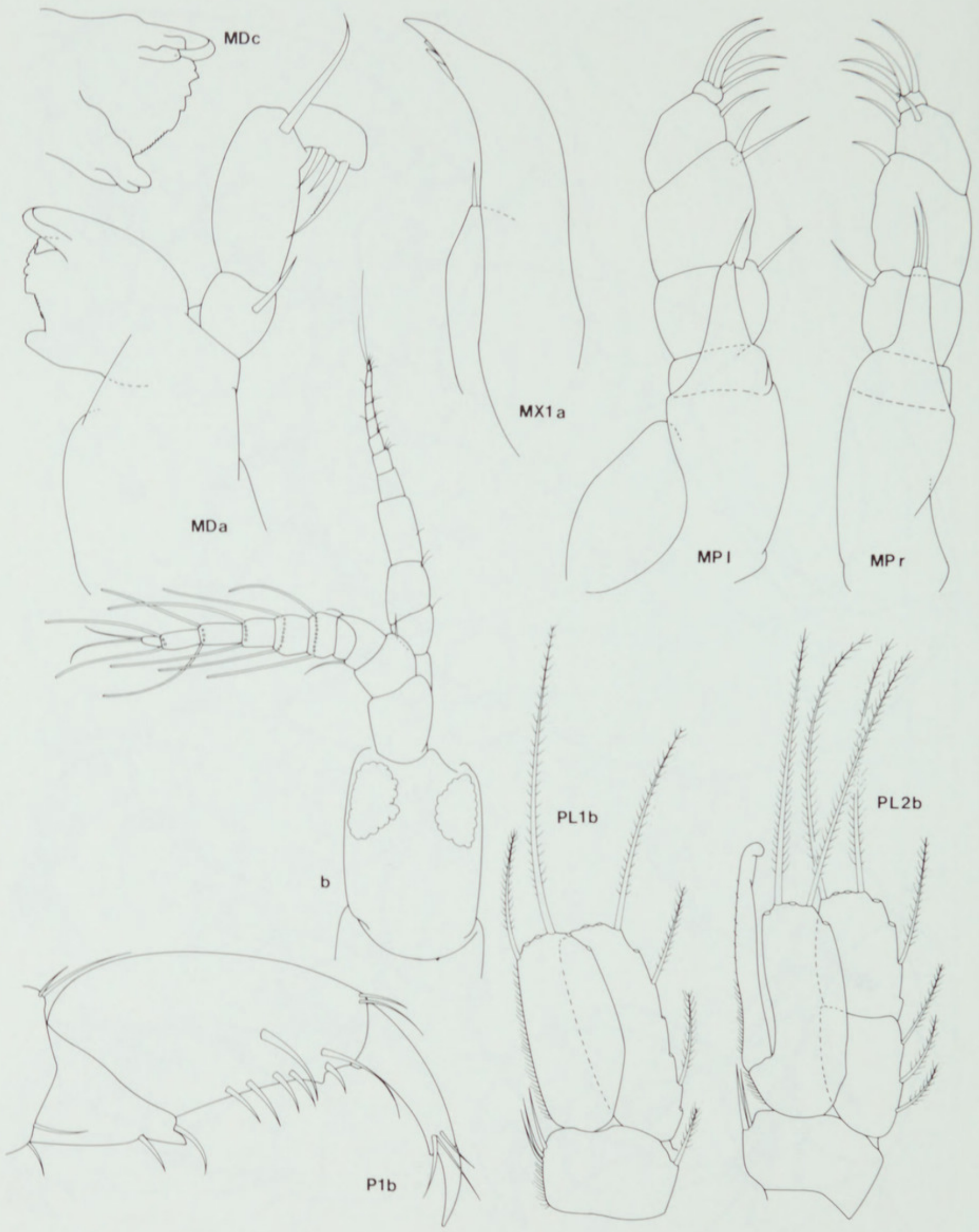

Figure 7. Kupellonura biriwa: a, holotype; b, paratype male, NMV J15021; c, juvenile, Hawkesbury River, AM P29754. 


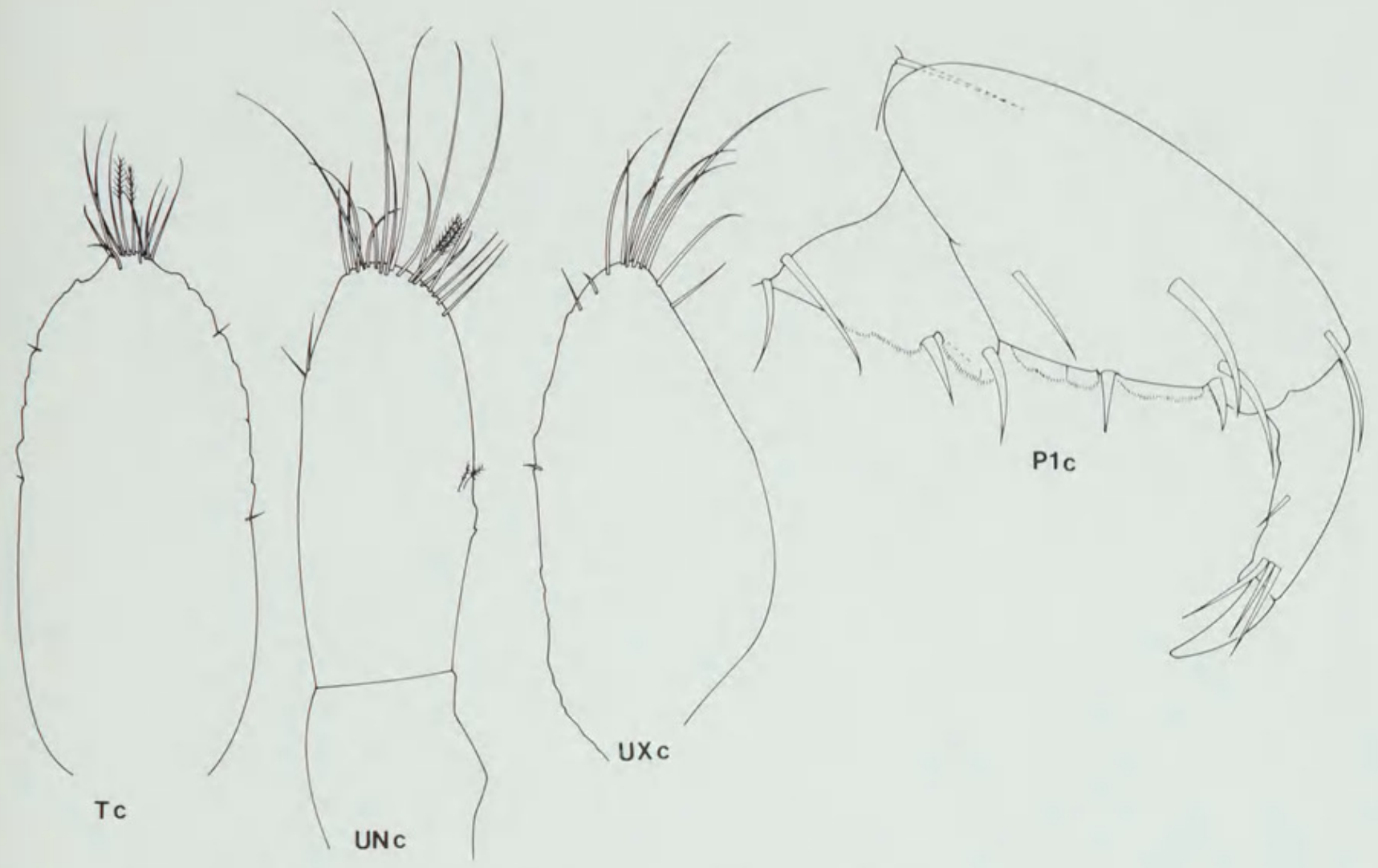

Figure 8. Kupellonura biriwa: c, juvenile, Hawkesbury River, AM P29754.

margin with proximal ridge bearing 2 recurved hooks; exopod not reaching as far as endopod or telson, 2.3 times as long as wide, laterally convex, medial margin with 2 recurved hooks proximally, dentate distally. Telson 3.2 times as long as wide, more or less parallel-sided, with narrowly rounded apex, with 2 pairs of recurved hooks proximally, dentate distally.

Distribution. New South Wales slope (known only from type locality).

Remarks. Kupellonura currawan differs from all other species in the genus in the presence of hooks on the margins of the telson and uropodal rami.

The pereopods are narrower than in $K$. biriwa, pereopods 1-3 have three marginal propodal spines rather than 2 , and the endopod of the pleopods is more rectangular. The figure of maxilla 1 is drawn more flat than that shown for $K$. biriwa.

\section{Kupellonura gidgee sp. nov.}

\section{Figure 10}

Material examined. 10 juveniles, 2 males, 4 mancas; to $3.4 \mathrm{~mm}$.

Holotype: Qld, Great Barrier Reef, Lizard Island $\left(14^{\circ} 40^{\prime} \mathrm{S}, 145^{\circ} 28^{\prime} \mathrm{E}\right)$, B. Kensley, Jan 1982 (stn BK-113), NMV J15027, juvenile, 3.4 mm (with 2 slides).
Paratypes: Type locality, NMV J15028, male, $2.8 \mathrm{~mm}$; J15029, 5 juveniles, 1 manca. Lizard Island, B. Kensley, Jan 1982 (stns BK-117, BK-127, BK-130), NMV J15030 (1 submale), J15031 (1), J15032 (1); (stn K-L5), USNM 211447 (2); (stn BK-129), QM colln(2). Lizard Is., Granite Head, $100 \mathrm{~m}$ offshore, coralline and other algae, $10 \mathrm{~m}$, G.C.B. Poore, 11 Dec 1987 (stn NQ-125), NMV J14751(1 male).

Other material. Qld. Lizard Island, B. Kensley, Jan 1982 (stn BK-115) NMV J15033 (1 manca).

NT. West side of Oxley Island $\left(11^{\circ} 00^{\prime} \mathrm{S}, 132^{\circ} 49^{\prime} \mathrm{E}\right), 14$ m, J.K. Lowry, 21 Oct 1982 (stn NT-82), NTM colln.

Diagnosis. Antenna 1 with 1 aesthetasc. Uropodal endopod 2.1 times as long as wide; exopod not reaching as far as endopod or telson, 2.1 times as long as wide, widest at proximal third, mesial margin gently convex, lateral margin strongly convex proximally. Telson basally narrow, 2.5 times as long as wide, lateral margins convex, dentate distally, apex subacute.

Male. Pereopod 1 propodus with 4 marginal setae.

Distribution. Queensland, northern Great Barrier Reef, Northern Territory coral cays.

Remarks. Kupellonura gidgee differs from K. biriwa in having slightly broader pereopodal propodi but setation is identical. The shorter and proximally 
182

GARY C. B. MORE AND HELEN M. LEW TON

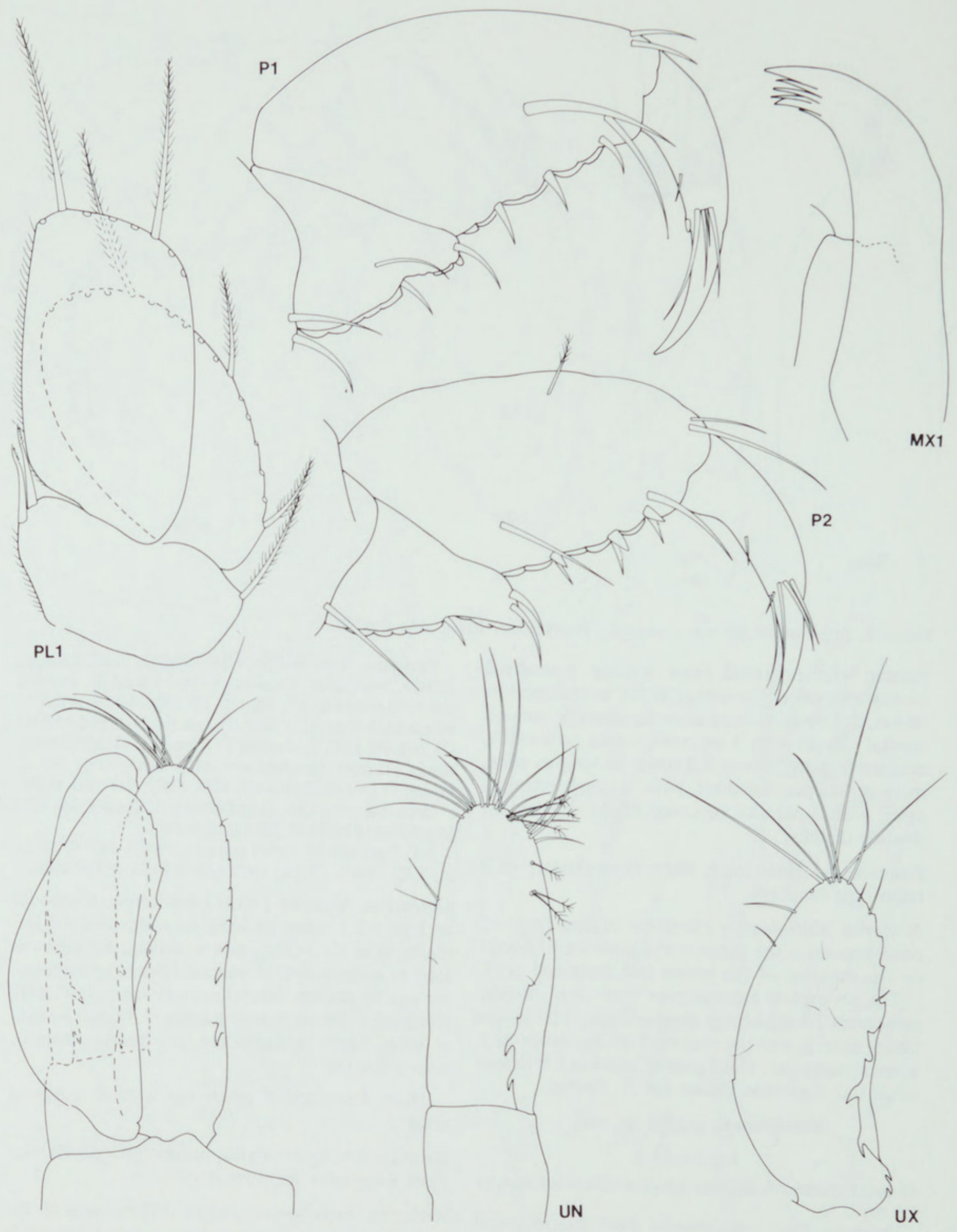

Figure 9. Kupellonura currawan, holotype. 


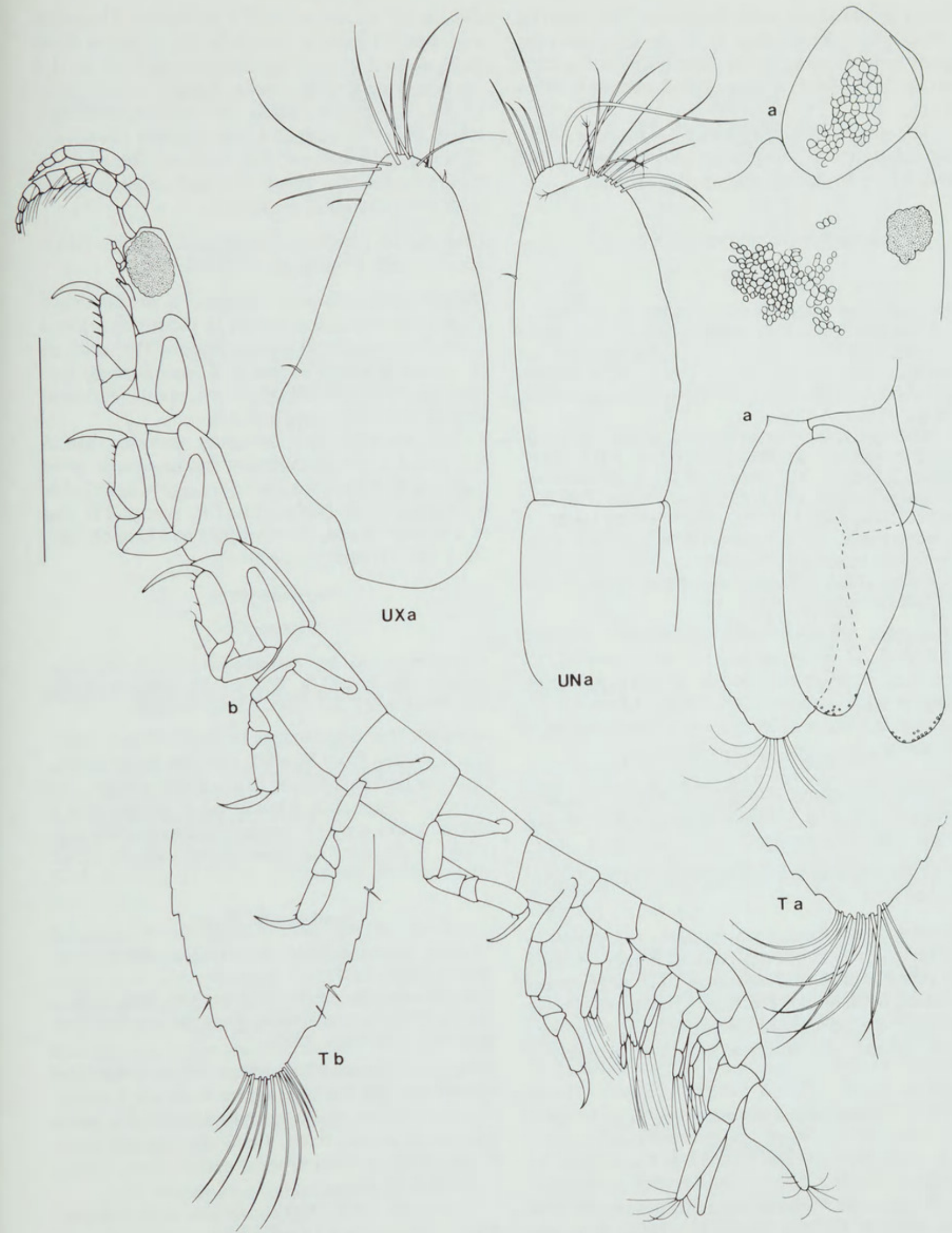

Figure 10. Kupellonura gidgee: a, holotype; b, paratype male, NMV J15029 (scale $=0.5 \mathrm{~mm}$ ). 
wider uropodal exopod is diagnostic. The male (fig. 10) displays the antenna 1, longer eyes and pleopods typical of the genus. The tessellated pattern on the integument of the head and antenna is shown in fig. 10 .

The species co-occurs with $K$. marrongie at Lizard Island (even being taken in the same sample) but differs in its wider uropodal exopod.

\section{Kupellonura marrongie sp. nov.}

Figure 11

Material examined. 6 juveniles, 1 male; to $2.8 \mathrm{~mm}$.

Holotype: Qld, Great Barrier Reef, Lizard Island $\left(14^{\circ} 40^{\prime} \mathrm{S}, 145^{\circ} 28^{\prime} \mathrm{E}\right)$, crest of patch reef in Lizard Island lagoon, coral rubble with algal turf, 2-3 m, B. Kensley, 11 Jan 1982 (stn BK-127), NMV J15034, juvenile, 2.8 mm (with 2 slides).

Paratypes: Type locality, QM colln, juvenile, Lizard Island, B. Kensley, Jan 1982 (stn BK-114), NMV J15035 (male). Lizard Is., Mrs Watsons Beach, dead coral rubble under bommie, 4 m, G.C.B. Poore, 11 Dec 1987 (stns NQ-118, NQ-120, NQ-121), NMV J14752-J14754 (3 juveniles). Qld, One Tree Island, $\left(23^{\circ} 30 \mathrm{~S}, 152^{\circ} 05 \mathrm{E}\right)$, One Tree Island lagoon, coarse sediment, $1.5 \mathrm{~m}, \mathrm{C}$. Short and J. Young, 17 Oct 1979 (AM Marine Ecology stn 2), AM P37928 (juvenile).

Diagnosis. Antenna 1 with 1 aesthetasc. Uropodal endopod 2.2 times as long as wide; exopod not reaching as far as endopod or telson, 3.3 times as long as wide, narrowly lanceolate. Telson basally narrow, 2.3 times as long as wide, lateral margins evenly convex, apex evenly rounded.

Male. Pereopod 1 propodus with 9 marginal setae, 1 very long. Telson and uropodal rami narrower than in juvenile.

Distribution. Queensland, Great Barrier Reef, coral lagoons.

Remarks. This species is most easily recognised by its very narrow uropodal exopod. Pereopods have very similar proportions to those of $K$. biriwa; their setation is identical. Pleopod 1 has 4 and 8 setae on the endopod and exopod respectively, fewer than in $K$. biriwa. The endopod is more rectangular.

\section{Kupellonura werawera sp. nov.}

Figure 12a

\section{Material examined. Unique.}

Holotype: Qld, Orpheus Island, Pioneer Bay (18 ${ }^{\circ} 37^{\prime} \mathrm{S}$, $\left.146^{\circ} 29^{\prime} \mathrm{E}\right)$, coral rubble, $9 \mathrm{~m}$, SCUBA, G.C.B. Poore and H.M. Lew Ton, 5 Dec 1982 (stn NQ-11), NMV J13036 (with 1 slide), juvenile, $3.1 \mathrm{~mm}$.
Diagnosis. Antenna 1 with 1 aesthetasc. Uropodal endopod 2.1 times as long as wide, widest in distal half; exopod as long as endopod and telson, 1.8 times as long as wide, mesial margin straight proximally and oblique distally, lateral margin strongly lobed, widest as midpoint, concave over distal half. Telson basally narrow, 2.4 times as long as wide, parallel-sided over most of length, apex truncate with blunt terminal projection.

Distribution. Northern Queensland, Orpheus Island (known only from type locality).

Remarks. Kupellonura werawera is distinguished from other Australian species by the strongly lobed uropodal exopod and unusual telson. The telson of $K$. werawera resembles that of $K$. mediterranea Barnard (see Wägele, 1981a) but its uropodal endopod and exopod are much broader.

Pereopodal propodi are lightly narrower than in $K$. biriwa but the arrangement and number of setae is identical. The mouthparts are indistinguishable from those of $K$. biriwa. The first pleopod is also of a similar shape, the endopod and exopod having 5 and 10 setae respectively.

\section{Kupellonura sp.}

\section{Figure $12 b$}

Material examined. Tas., off east coast $\left(42^{\circ} 37^{\prime} \mathrm{S}, 148^{\circ} 20 \mathrm{E}\right)$, $102 \mathrm{~m}$, epibenthic sled, R. Wilson, 9 Oct 1984 (stn CSIRO SO5/84/1), NMV J15054 (1 manca, $4.2 \mathrm{~mm}$ ).

Remarks. This single manca from Bass Strait resembles $K$. biriwa from Western Port but differs sufficiently to probably belong to a separate species. The manca is larger than mancas of $K$. biriwa, has a much broader uropodal exopod and longer and narrower endopod. Its description awaits adult material.

\section{Neohyssura Amar}

Neohyssura Amar, 1953: 353.-Wägele, 1981a: 70, 71, 72, 75.-1981b: 72-73.

Horolanthura Menzies and Frankenberg, 1966: 41-42.Wägele, 1981b: 82 (type species - Horolanthura irpex Menzies and Frankenberg, 1966).

Diagnosis. Antenna 1 flagellum of 4 articles, with 1 aesthetasc on the last article. Antenna 2 peduncle without stout plumose setae. Mandibular molar process an acute, fixed, finely denticulate spine; palp 3-articled. Maxillipedal endite short, broad; palp of 5 articles.

Pereopods 2 and 3 palm oblique with marginal spines. Pereopods 4-7 carpus triangular, carpus and propodus each with 1 posterodistal spine. Pleopodal rami both with several marginal setae. Uropo- 

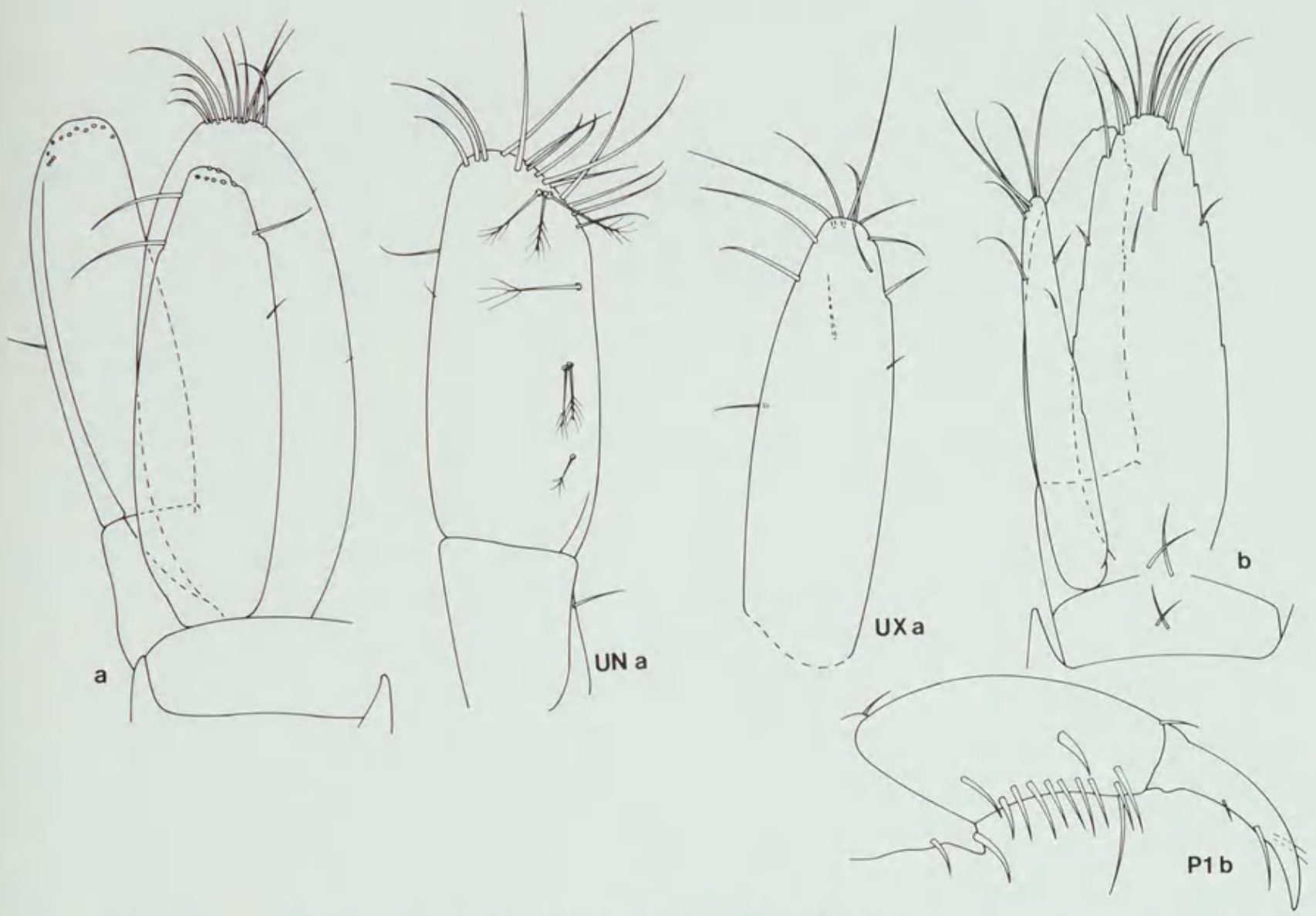

Figure 11. Kupellonura marrongie: a, holotype; b, paratype male, NMV J15035.

dal endopod free, longer than peduncle; exopod linear with cuticular spines on mesial margin. Telson as long as uropod, triangular, with cuticular spines on lateral margins.

Type species. Hyssura spinicauda Walker, 1901 (monotypy).

Remarks. Neohyssura is most similar to Kupellonura with which it shares undifferentiated pereopods, uropods, pleopods and mandibular and maxillipedal palps. The evenly tapering telson, and uropodal and telsonic spines are the apomorphies defining the genus. Negoescu and Wägele (1984) listed three species from the Atlantic Ocean, Indian Ocean and Mediterranean, and Wägele (1987) added a fourth from interstitial habitats in the Cape Verde Islands.

\section{Neohyssura bilara sp. nov.}

Figures 13, 14

Material examined. 2 juveniles, 1 female, 1 sub-male; to $4.2 \mathrm{~mm}$.
Holotype: Qld, Shoalwater Bay, 140 m off Little Bank Beach, Triangular Island $\left(22^{\circ} 30^{\prime} \mathrm{S}, 150^{\circ} 31^{\prime} \mathrm{E}\right)$, intertidal mudflat, J. Lewis, 13-16 Sep 1981, NMV J15037, gravid female, $4.2 \mathrm{~mm}$ (with 2 slides).

Paratypes: Type locality, QM colln, juvenile; NMV J15038, submale. Shoalwater Bay, Triangular Island, 50 m offshore, intertidal mudflat, J. Lewis, 3-6 Nov 1982, NMV J13039, juvenile.

Description. Head wider than long, rounded rostrum, without eyes. Antenna 1 peduncle, articles 1 and 2 with 1 and 3 fine brush-setae respectively; flagellum of 4 articles, last minute, with terminal aesthetasc. Antenna 2 flagellum of 8 articles.

Mandible with bluntly toothed incisor; lamina dentata coarsely toothed distally, finely toothed proximally; molar process a fixed, acute tooth, finely denticulate distally; palp of 3 articles, last with short terminal seta. Maxilla 1 inner lobe with 1 seta; outer lobe strongly curved, with 7 fixed teeth. Maxilliped with short broad endite bearing 1 seta; palp of 5 articles bearing $0,1,2,2,3$ setae.

Pereopod 1 carpus produced as seta-bearing tooth; propodus triangular, palm oblique, with 2 


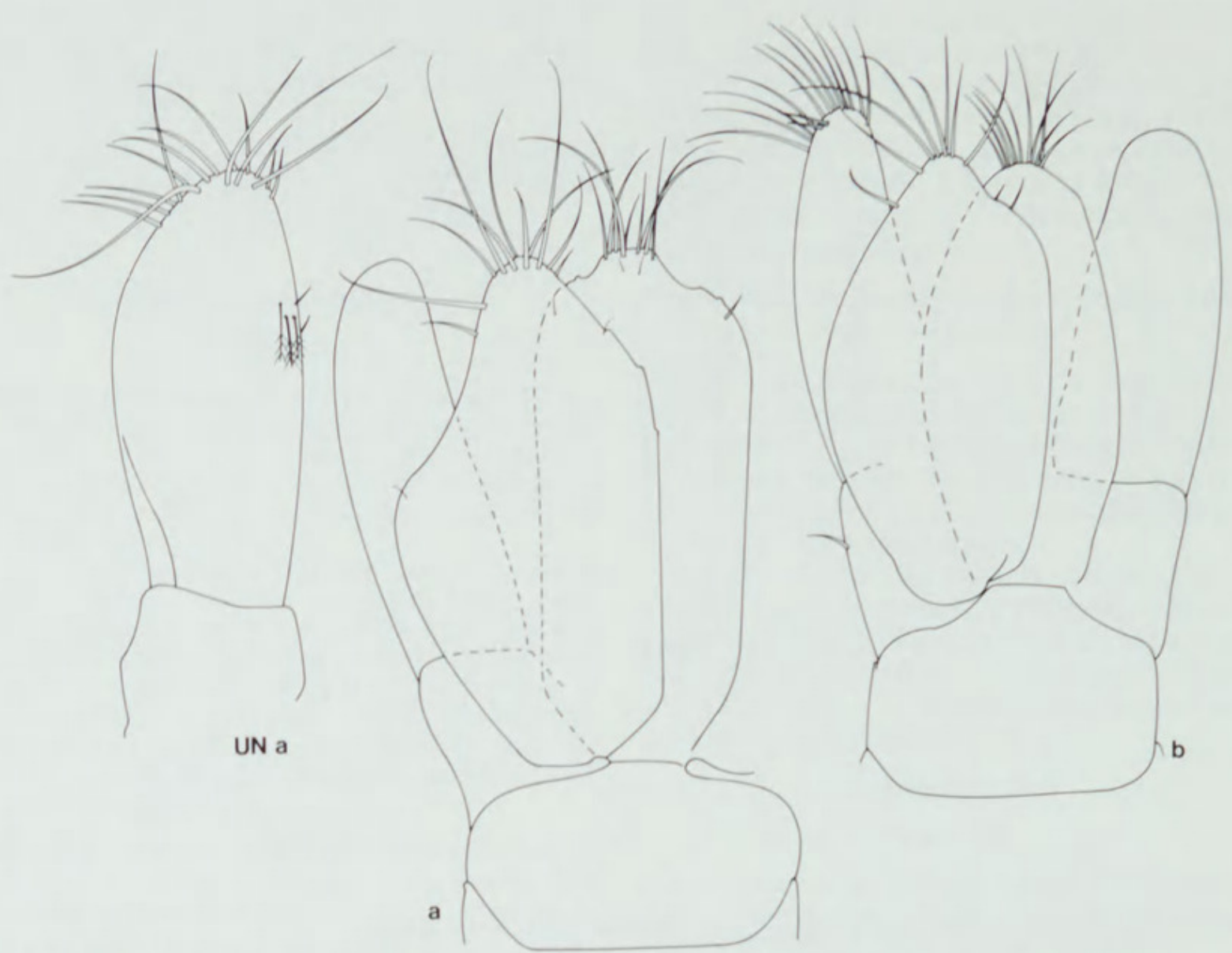

Figure 12. a, Kupellonura werawera, holotype. b, Kupellonura sp., manca, NMV J15054 (uropodal exopods drawn flat in situ).

mesial setae, 3 marginal setae and 2 submarginal setae distally. Pereopod 2 carpus strongly produced; propodus palm with 3 bifid spines with blade-like setae between. Pereopod 3 similar but smaller. Pereopods 4-7 carpus with posterodistal spine, propodus with porterodistal spine (plus accessory setae on pereopod 7).

Pleopods 1-5 peduncle with 2 mesial setae; endopod with 5 plumose setae; exopod smaller, with 9 plumose setae. Pleonal epimera 1-4 with 2-3 submarginal plumose setae, epimeron 5 with none. Uropodal endopod 3 times as long as peduncle, with 5 dorsal brush-setae, 5 marginal simple setae and 11 distoventral simple setae; exopod 4-5 times as long as wide, with 3 strong spines, posteroventrally directed along mesial margin, 4 marginal and 6 dorsal setae at apex. Telson widest proximally, 2.2 times a long as wide, triangular, with 3-4 spines on each side, 8 apical setae.

Submale. Antenna 1 flagellum of a long article without aesthetases and terminal article with 1 aes- thetasc as in juvenile. Pereopod 1 not differentiated. Appendix masculina longer than endopod.

Distribution. Central Queensland, bays.

Remarks. This new species is closest to $N$. spinicauda (Walker). Wägele (1981b) did not see a maxillipedal endite on this species but otherwise the species differs only in minor aspects of setation and proportions. The South African N. skolops Kensley is significantly different, especially in the tail fan and well-developed maxillipedal endite. Its endite, the toothed mandibular lamina dentata and molar process are more Kupellonura-like.

\section{Xenanthura Barnard}

Xenanthura Barnard, 1925; 138.-Wägele, 1981a: 69 75. $-1981 \mathrm{~b}: 84$.

Diagnosis. Antenna 1 flagellum of 3 articles, with 1 aesthetasc on last article. Antenna 2 peduncle with 1 or 2 stout plumose setae (in addition to typical brush-setae). Mandibular molar process an ar- 


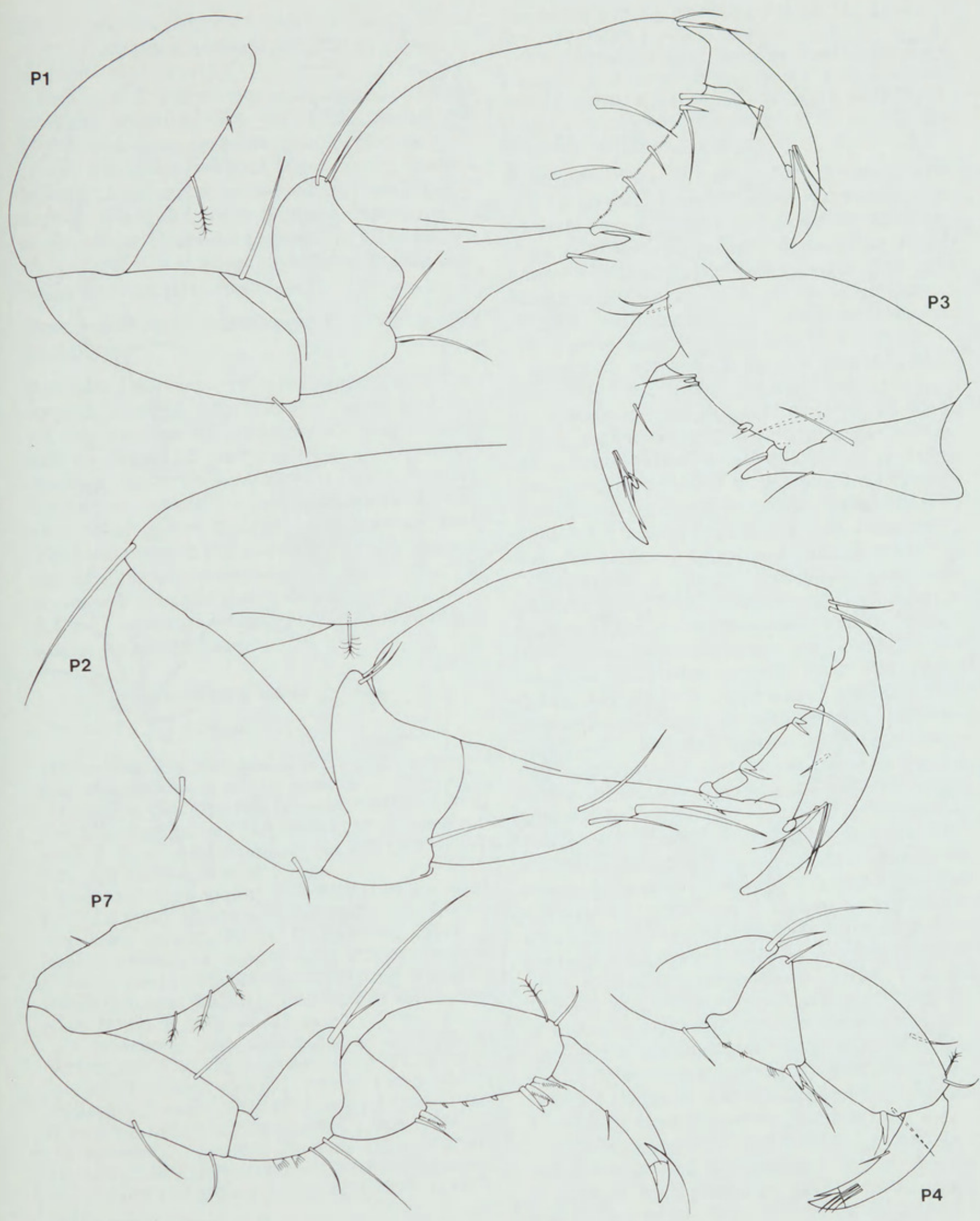

Figure 13. Neohyssura bilara, holotype. 


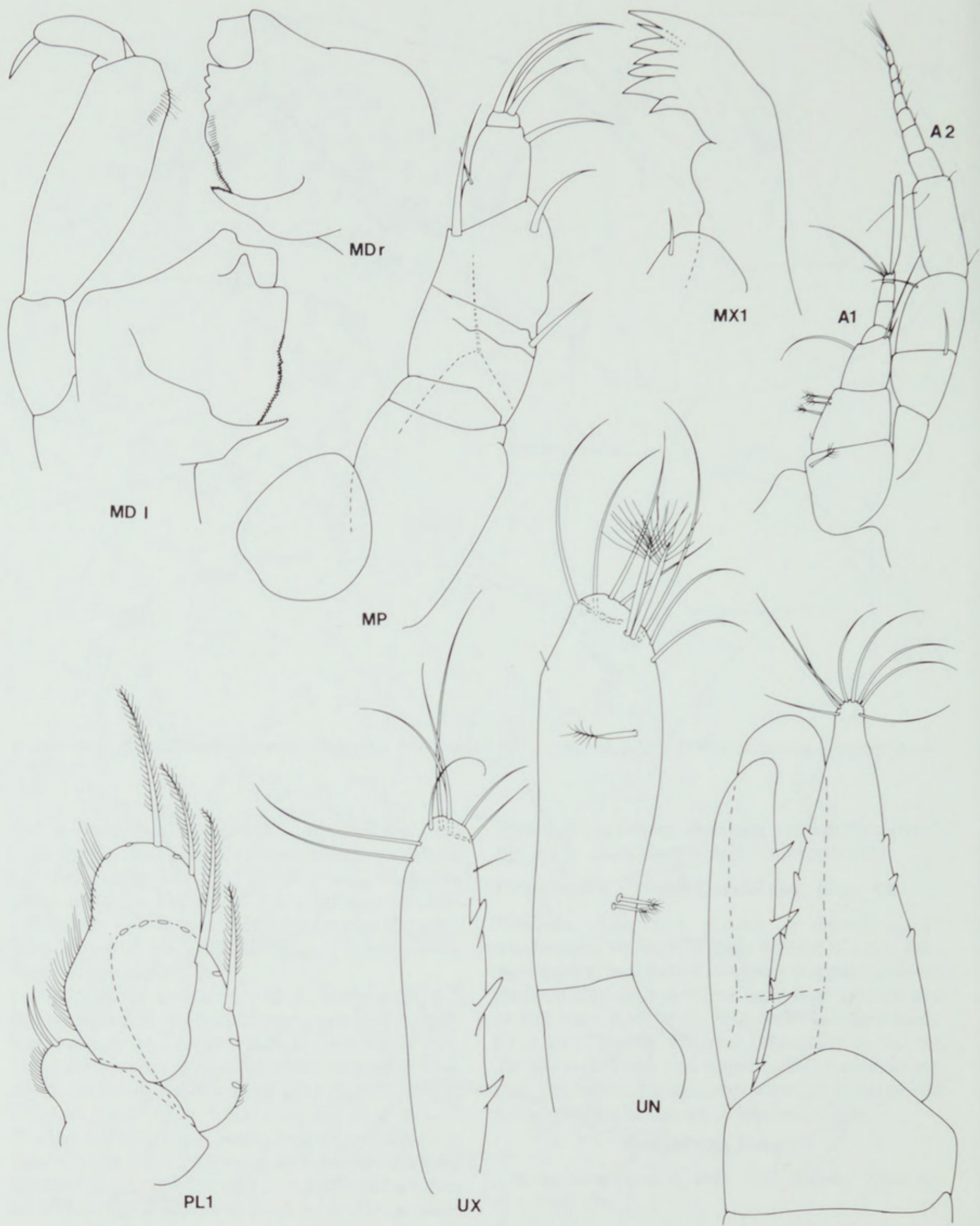

Figure 14. Neohyssura bilara, holotype (uropodal exopod in ventral view). 
ticulating spine; palp a single article with terminal setae. Maxillipedal endite short; palp of 5 fused or partially fused articles.

Pereopod 2 palm transverse, carpus strongly produced. Pereopod 3 broad distally, merus and carpus with long posterior setae. Pereopods 4-7 carpus triangular, without free anterior margin, without carpal and propodal spines. Pleopodal endopods triangular, with terminal seta; exopods ovoid, setose. Uropodal endopod fused to peduncle; exopod ovoid. Telson much shorter than uropods, tapering to excavate apex.

Type species. Xenanthura brevitelson Barnard, 1925 (monotypy).

Remarks. The presence of a molar spine, mandibular palp article and maxillipedal endite are noted for the first time for Xenanthura. These features were confirmed on the type species, $X$. brevitelson (material from Gulf of Mexico, NMV J11657). Similarities between this genus and Belura gen. nov. were noted earlier. George and Negoescu (1985) listed and mapped the distribution of the five species of Xenanthura then known (their species $X$. acuticauda is herein removed to Belura gen. nov). All are tropical or warm-temperate as is the new species described there.

\section{Xenanthura ulawa sp. nov.}

\section{Figures $15-17$}

Material examined. 84 juveniles, to $5.2 \mathrm{~mm} ; 1$ female, 4.4 $\mathrm{mm} ; 48$ males, to $4.3 \mathrm{~mm}$; 10 mancas.

Holotype: QId, One Tree Island $\left(23^{\circ} 30^{\prime} \mathrm{S}, 152^{\circ} 05^{\prime} \mathrm{E}\right)$, One Tree Island lagoon, "Shark Alley", $1.5 \mathrm{~m}$, coarse sediment, C. Short and J. Young, 17 Oct 1979 (AM stn OTI 3.2), AM P29685, juvenile, $5.2 \mathrm{~mm}$.

Paratypes: Type locality AM P29653 (4 juveniles), P29654 (1 male), P29655 (2 juveniles), P29656 (female in tube, male, manca), P29657 (2 juveniles), P29681 (1 manca), P29682 (1 juvenile, 2 males), P29684 (1 manca), P29686 (1 manca), P29689 (1 juvenile), P29690 (1 male), P29691 (1 manca), P29994 (1 juvenile), P30061 (1 manca), NMV J15040 ( 8 juveniles, 2 males).

Other material. Qld, bays and shelf off Townsville $\left(19^{\circ} 16^{\prime} \mathrm{S}, 146^{\circ} 49^{\prime} \mathrm{E}\right)$, various collections: NMV J15041 (33 juveniles, 23 males), J15042 (1 manca, 1 male), J15043 ( 3 juveniles, 3 males), J15044 (1 juvenile, 1 male), J15045 (1 juvenile), AM P37927 (10 juveniles, 5 males), QM colln (10 juveniles), 5 males). Fantome Island $\left(18^{\circ} 40^{\prime} \mathrm{S}\right.$, $\left.146^{\circ} 31^{\prime} \mathrm{E}\right)$, NMV J15044 (1 male, 1 juvenile). Shoalwater Bay $\left(22^{\circ} 30^{\prime} \mathrm{S}, 150^{\circ} 3 \mathrm{I}^{\prime} \mathrm{E}\right)$, J. Lewis, 1982, NMV J15057 (1 male).

NT. New Year Island ( $\left.10^{\circ} 54^{\prime} \mathrm{S}, 133^{\circ} 02^{\prime} \mathrm{E}\right), 10-14 \mathrm{~m}, \mathrm{~J} . \mathrm{K}$. Lowry and G.C.B. Poore, 14 Oct 1982, NMV J15048 (1 juvenile), J15049 (1 juvenile) J15050 (1 manca). Oxley Island $\left(11^{\circ} 00^{\prime} \mathrm{S}, 132^{\circ} 49^{\prime} \mathrm{E}\right), 14 \mathrm{~m}$, muddy sand, J.K. Lowry, 21 Oct 1982, NTM colln (1 juvenile, 3 males). East Point,
Fannie Bay $\left(11^{\circ} 24^{\prime} \mathrm{S}, 130^{\circ} 48^{\prime} \mathrm{E}\right), 8-10 \mathrm{~m}$, J.K. Lowry, 26 Oct 1982, NMV J15051 (1 juvenile).

WA. North-west Shelf, between Port Hedland and Dampier $\left(18^{\circ} 41^{\prime} \mathrm{S}, 118^{\circ} 39^{\prime} \mathrm{E}\right), 134 \mathrm{~m}$, G.C.B. Poore and H.M. Lew Ton, 4 Jun 1983 (stn NWA-21), NMV J15052 (1 juvenile); $\left(19^{\circ} 38^{\prime} \mathrm{S}, 118^{\circ} 06^{\prime} \mathrm{E}\right), 49 \mathrm{~m}, 13$ Jun 1983 (stn NWA-56), J15053 (1 juvenile).

Description. Body 20 times as long as wide, colourless. Head wider than long, truncate rostrum, dorsolateral eyes. Antenna 1 with fine brush-setae and stout tufted seta on article 2 of peduncle; flagellum of 3 articles, first with brush-seta, third with 1 aesthetasc, 2 plumose and 1 simple setae. Antenna 2 article 5 with fine brush-setae dorsally and stout tufted-setae ventrally; flagellum of 5 articles.

Mandible with blunt incisor; lamina dentata of 3 finely denticulate flattened plates; molar process an articulating spine with fine denticles along length; palp a single article with apical seta. Maxilla 1 inner ramus a broad lobe; outer ramus strongly curved, with 1 fixed spine, 3 articulating setae, plus 1 finer seta innermost. Maxilliped with short endite bearing 1 apical seta; palp a single plate with 3-4 mesial, 1 lateral and 3 distal setae.

Pereopod 1 carpus slightly produced posterodistally, with pectinate and stout setae on margin; propodus triangular; palm slightly oblique, with consistent pattern of pectinate and blade-like setae and stout setae, 4 mesial setae. Pereopod 2 carpus strongly produced to end of propodus, with 9 posterior and 2 anterior teeth; propodal palm oblique, with consistent pattern of 7 teeth and marginal setae. Pereopod 3 merus as broad as greatest length, posterior margin convex, with 11 triangular denticles and 9 long posterodistal setae; carpus posterodistally lobed, 1-2 cuticular denticles proximally, 20 long setae distally; propodus ovate, palm obscured; dactylus constricted near base. Pereopods 4-7 with few setae; merus, carpus and propodus with posterior marginal and submarginal digitiform denticles, dactylus with anterior and posterior denticles; propodus of pereopods $4-7$ with $1,2,3$, and 3 strong mesiodistal setae respectively. Pleopod 1 peduncle with 2 setae on narrow mesial lobe; both rami of 1 article; endopod triangular, with 1 distal seta; exopod narrow, with 12 plumose setae. Pleopods 2-5 similar to first. Pleonal epimera 1-4 with 2 marginal setae, epimeron 5 with none.

Uropodal peduncle and endopod fused, with broad ventromesial shelf bearing 4 large brush-setae in shallow distal concavity; apex rounded-acute, with 3 finer brush-setae, distolateral margin with 11 setae; exopods overlapping, 1.5 times as broad as long, 6 setae posteriorly. Telson widest proximally, apex about half basal width, concave, with 2 brush-setae near midpoint and short seta laterally. 


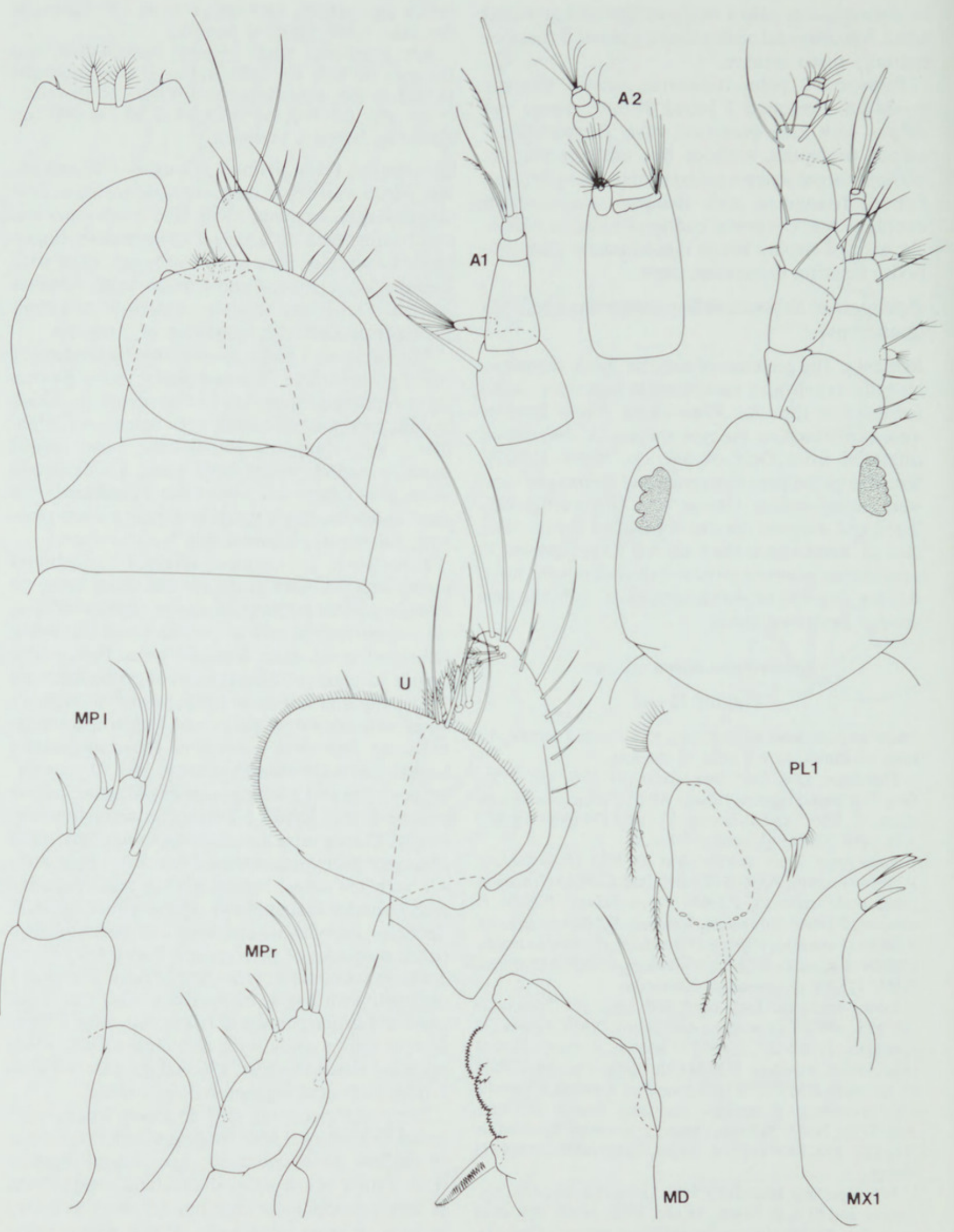

Figure 15. Xenanthura ulawa, holotype (antennae in ventral view). 


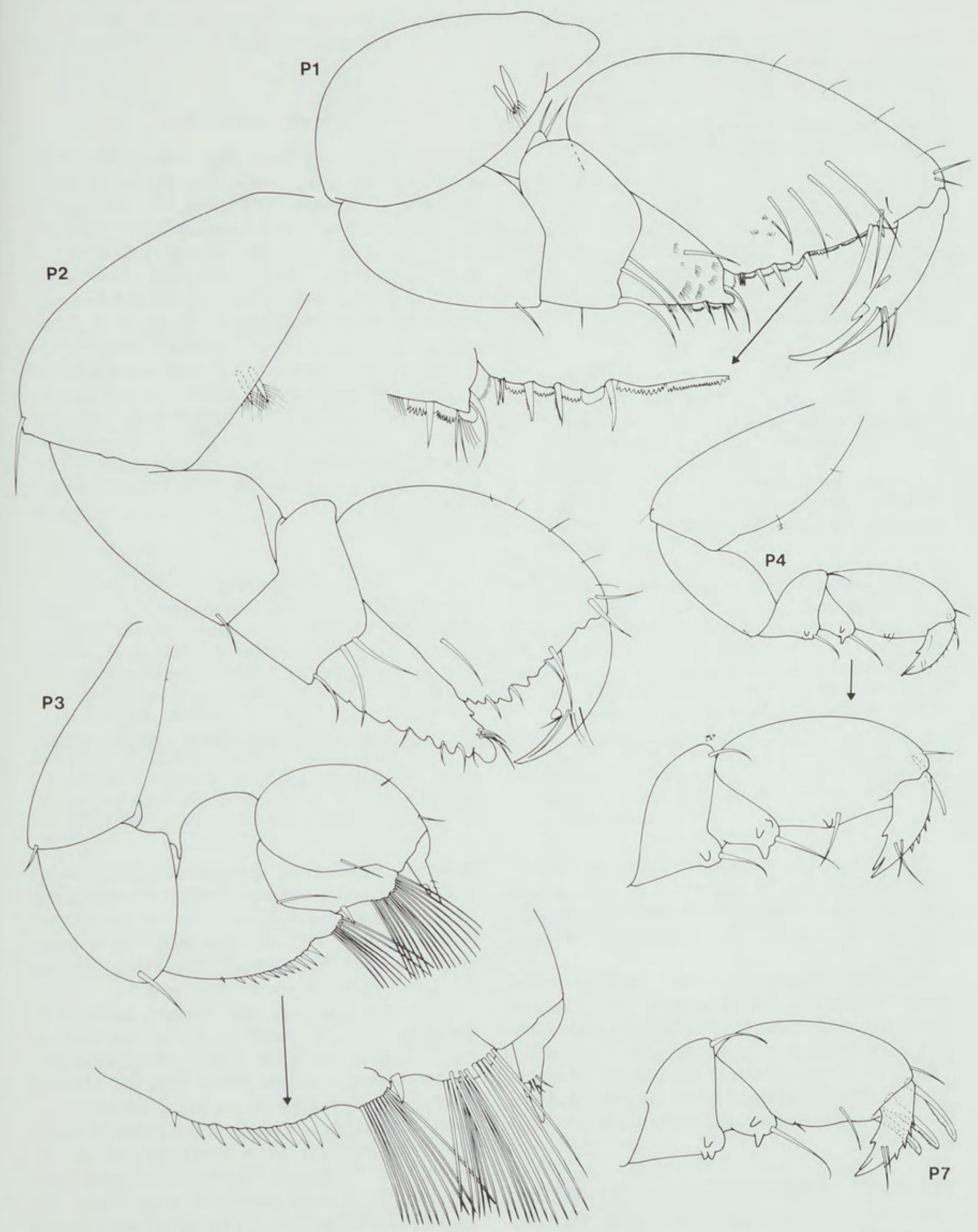

Figure 16. Xenanthura ulawa, holotype. 


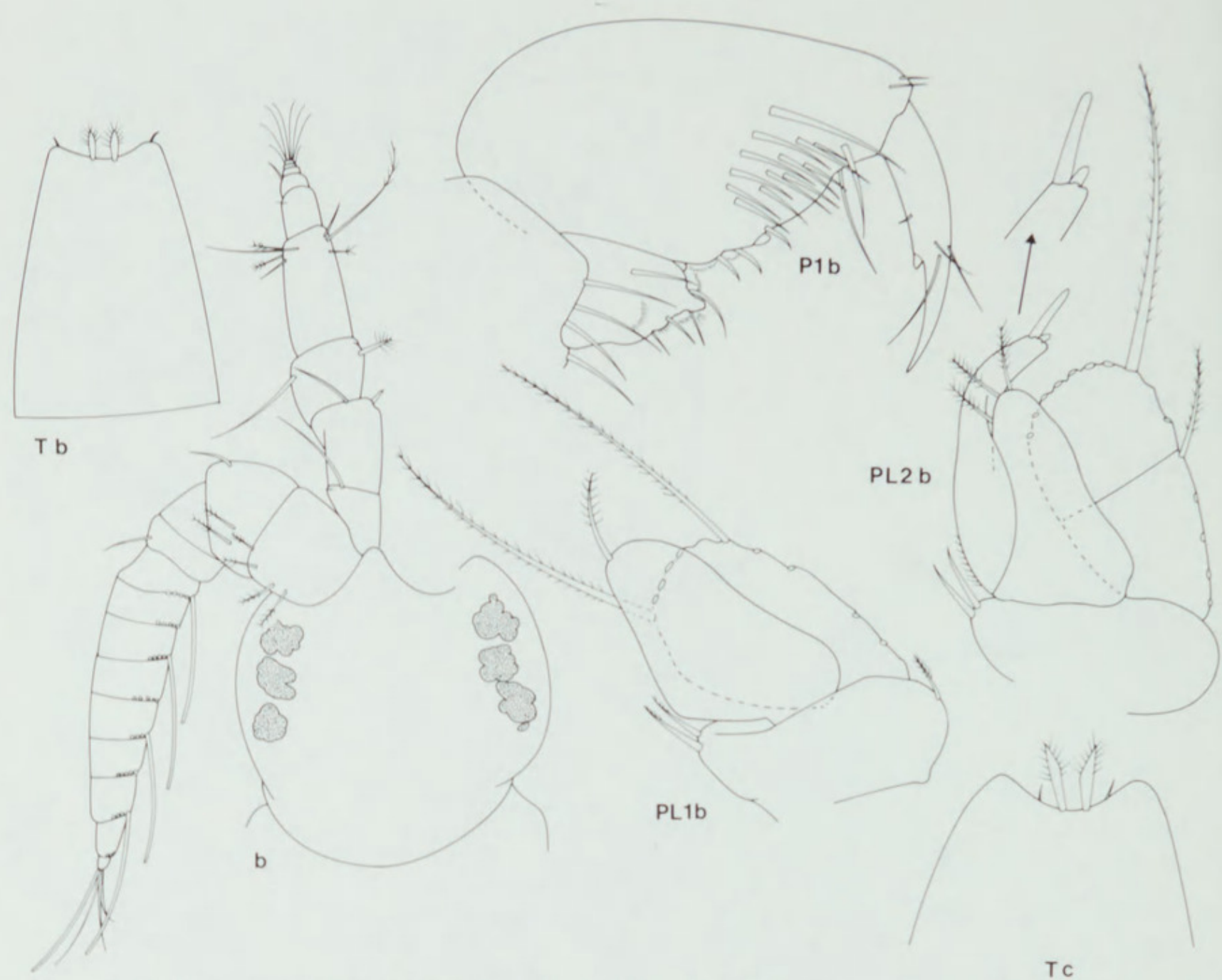

Figure 17. b, Xenanthura ulawa, paratype male, AM P29690. c, Xenanthura brevitelson, juvenile, Gulf of Mexico, NMV J11657.

Male. Head round, rostrum acute, lateral eyes tripartite. Antenna 1 flagellum of 10 articles: first short, articles 2-9 each bearing about 6 aesthetases, terminal article minute. Antenna 2 without tufted-seta.

Pereopod 1 similar to juvenile, with 13 mesial setae. Pereopods 2-7 same as in juvenile. Pleopod 1 peduncle more rectangular, exopod broader. Pleopod 2 with triangular endopod with 3 or 4 setae; broad curved appendix masculina, with 1 short and 1 longer articulating blunt spines apically; pleopods $2-5$ exopods 2 -articulate. Telson more elongate than in juvenile.

Distribution. Tropical north-eastern, northern and north-western Australia, shelf and lagoonal sediments.
Remarks. Xenanthura ulawa is recorded from a wide geographical area of tropical Australia and from both reef and shelf environments but showed little variability. The holotype differs from many other specimens in possessing one rather than two denticles on the carpus of pereopod 3 .

The numbers of setae are constant between individuals and are useful to distinguish species. Xenanthura ulawa differs from $X$. brevitelson Barnard in having a broader telson (see fig. 17) with close lateral setae and more long setae on pereopod 3. The blade-like setae on the palm of pereopod 1 is replaced by a pectinate one in $X$. brevitelson. X. sinaica Wägele differs most obviously in pereopods 2 and 3 , narrower telson and longer uropodal exopod. X. bacescui Negoescu has a triangular uropodal exopod and less tapered tel- 
son. $X$. orientalis and $X$. linearis Pillai have a toothed carpus on pereopod 3 .

A single female (gravid but without oostegites) was found in a thick mucilaginous tube.

\section{Acknowledgements}

This contribution was made possible through a grant from the Australian Biological Resources Study. We are especially grateful to Graham Milledge who inked the figures. For the loan or gift of material we thank Jim Lowry and Alan Jones (Australian Museum), John Lewis (Materials Research Laboratory, Melbourne), and Brian Kensley (U.S. National Museum of Natural History).

Field work to collect this material was supported by Australian Biological Resources Study and Marine Science and Technologies grants. We appreciate the co-operation of CSIRO Division of Fisheries, the Northern Territory Museum of Arts and Sciences (especially A.J. Bruce), and the Australian Institute of Marine Sciences (especially Paul Sammarco).

\section{References}

Amar, R., 1953. Isopodes marins du littoral Corse. Bulletin de la Société Zoologique de France 77: 345-355.

Barnard, K.H., 1925. A revision of the family Anthuridae (Crustacea, Isopoda), with remarks on certain morphological peculiarities. Journal of the Linnean Society 36: 109-160.

George, R.Y. and Negoescu, I., 1985. Anthuridean isopods (Crustacea, Isopoda, Anthuridea) from the subantarctic islands - South Georgia, Elephant, South Orkney and Falkland. Travaux du Museum d'Histoire Naturelle Grigore Antipa 27: 19-47.
Kensley, B., 1975. Marine Isopoda from the continental shelf of South Africa. Annals of the South African Museum 67: 35-89.

Kensley, B., 1978. A new genus and species of anthurid isopod from deep water off the east coast of the United States. Proceedings of the Biological Society of Washington 91: 558-562.

Kensley, B., 1982a. Revision of the southern African Anthuridea (Crustacea, Isopoda). Annals of the South Arican Museum 90: 95-200.

Kensley, B., 1982b. Anthuridea (Crustacea: Isopoda) of Carrie Bow Cay, Belize. Smithsonian Contributions to the Marine Sciences 12: 321-353.

Menzies, R.J. and Frankenberg, D., 1966. Handbook on the Common Marine Isopod Crustacea of Georgia. University of Georgia Press: Athens.

Negoescu, I. and Wägele, J.W., 1984. World list of the anthuridean isopods (Crustacea, Isopoda, Anthuridea). Travaux du Museum d'Histoire Naturelle Grigore Antipa 25: 99-146.

Norman, A.M. and Stebbing, T.R.R., 1886. On the Crustacea lsopoda of the "Lightning", "Porcupine", and "Valorous" expeditions. Transactions of the Zoological Society of London 12: 77-141.

Wägele, J.W., 1981a. Zur Phylogenie der Anthuridea (Crustacea, Isopoda) mit Beitragen zur Lebenweise, Morphologie, Anatomie und Taxonomie. Zoologica, Stuttgart 132: 1-127.

Wägele, J.W., 1981b. Study of the Hyssuridae (Crustacea: Isopoda: Anthuridea) from the Mediterranean and the Red Sea. Israel Journal of Zoology 30: 47-87.

Wägele, J.W., 1983. On the homology of antennal articles in Isopoda. Crustaceana 45: 31-37.

Wägele, J.W., 1985. Two new genera and twelve new species of Anthuridea (Crustacea: Isopoda) from off the West Coast of New Zealand. New Zealand Journal of Zoology 12: 363-423.

Wägele, J.W., 1987. Neohyssura atlantica n. sp. from the Cape Verde Islands (Crustacea: Isopoda: Anthuridea). Bulletin, Zoölogisch Museum, Universiteit van Amsterdam 11: 13-19. 


\section{$2 \mathrm{BHL}$ Biodiversity Heritage Library}

1988. "A generic review of the Hyssuridae (Crustacea: Isopoda) with a new genus and a new species from Australia." Memoirs of the Museum of Victoria 49, 169-193.

View This Item Online: https://www.biodiversitylibrary.org/item/122418

Permalink: https://www.biodiversitylibrary.org/partpdf/50235

\section{Holding Institution}

Museums Victoria

\section{Sponsored by}

Atlas of Living Australia

\section{Copyright \& Reuse}

Copyright Status: Permissions to digitize granted by rights holder.

This document was created from content at the Biodiversity Heritage Library, the world's largest open access digital library for biodiversity literature and archives. Visit BHL at https://www.biodiversitylibrary.org. 